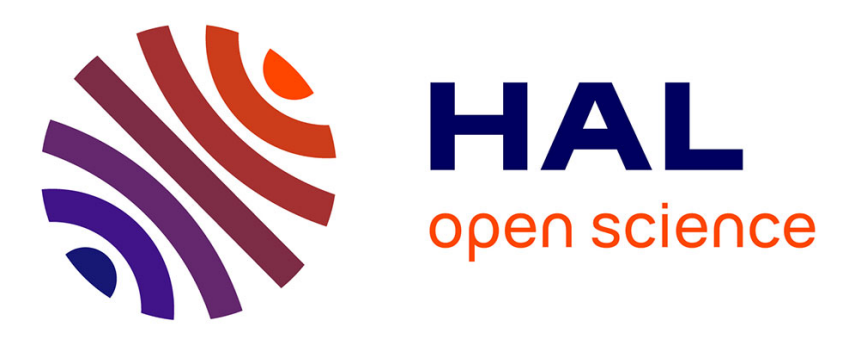

\title{
Plume-induced continental rifting and break-up in ultra-slow extension context: Insights from 3D numerical modeling
}

Alexander Koptev, Evgueni Burov, Taras Gerya, Laetitia Le Pourhiet, Sylvie Leroy, Eric Calais, Laurent Jolivet

\section{To cite this version:}

Alexander Koptev, Evgueni Burov, Taras Gerya, Laetitia Le Pourhiet, Sylvie Leroy, et al.. Plumeinduced continental rifting and break-up in ultra-slow extension context: Insights from 3D numerical modeling. Tectonophysics, 2018, 746, pp.121-137. 10.1016/j.tecto.2017.03.025 . hal-01500770

\section{HAL Id: hal-01500770 https://hal.sorbonne-universite.fr/hal-01500770}

Submitted on 3 Apr 2017

HAL is a multi-disciplinary open access archive for the deposit and dissemination of scientific research documents, whether they are published or not. The documents may come from teaching and research institutions in France or abroad, or from public or private research centers.
L'archive ouverte pluridisciplinaire HAL, est destinée au dépôt et à la diffusion de documents scientifiques de niveau recherche, publiés ou non, émanant des établissements d'enseignement et de recherche français ou étrangers, des laboratoires publics ou privés. 
Plume-induced continental rifting and break-up

\title{
in ultra-slow extension context: Insights from 3D numerical modeling
}

\author{
Alexander Koptev ${ }^{1}$, Evgueni Burov ${ }^{1 \mp}$, Taras Gerya ${ }^{2}$, Laetitia Le Pourhiet ${ }^{1}$, \\ Sylvie Leroy ${ }^{1}$, Eric Calais ${ }^{3}$, Laurent Jolivet ${ }^{4}$
}

${ }^{1}$ Sorbonne Universités, UPMC Univ. Paris 06, CNRS, Institut des Sciences de la Terre de Paris (iSTeP), 4 place Jussieu 75005 Paris, France

${ }^{2}$ ETH-Zurich, Institute of Geophysics, Sonnegstrasse 5, Zurich, Switzerland

${ }^{3}$ Ecole Normale Supérieure, Dept. of Geosciences, PSL Research University, CNRS UMR8538, Paris, France

${ }^{4}$ Univ d'Orléans, ISTO, UMR 7327, 45071 Orléans, France

${ }^{\Phi}$ Deceased 9 October 2015

\begin{abstract}
Breaking the lithosphere in extension without exceeding the driving far-field forces available on Earth is a tough quantitative modeling problem. One can tear it apart by propagation of an existing oceanic basin or weakness zone or one must assist rifting with magmatic processes, which drop the effective stress and weakens locally the lithosphere. While previous 3D models have demonstrated that non-cylindrical plumes produce almost cylindrical rift structures in a lithosphere under slight far-field loading, our contribution goes one step further by producing models of complete continental break-up. We investigate in details how the rheological stratification of the continental lithosphere interacting with active mantle plume influences the geometry and dynamics of rifting to continental break-up in 3D. We find that, irrespective of the rheological stratification, a plume-induced rifting process
\end{abstract}


always occurs in two stages: an early crustal rifting stage and a late lithospheric necking (breakup) stage. In case of a rheologically decoupled lithosphere, initial brittle deformation is concentrated in the upper crust and strongly localized due to compensating ductile flow of lower-crustal material (core complex extension mode). On the contrary, rheological coupling between upper crust and lithospheric mantle results in highly distributed brittle deformation in the crust above mantle plume head (wide rift mode). Both core complex-like and wide rifting are followed by an abrupt transition to narrow rift stage when a localized ascent of mantle plume material focuses high strain along faults zones breaking through the entire lithosphere. The Main Ethiopian Rift, the Basin and Range province, and the East Shetland Basin may be natural examples of regions that have passed through these two stages of extension. Acrossstrike and along-strike asymmetry of break-up patterns arising spontaneously within initially symmetrical and laterally homogenous environment seems to be an intrinsic characteristic of plume-induced rifting.

Keywords: continental rifting; core complex mode; wide rift mode; narrow rift; plumelithosphere interactions; extensional tectonics; lithosphere rheology; 3D numerical modeling. 


\section{Introduction}

Continental rifting is a fundamental geodynamic process that is described as stretching and thinning of the whole lithosphere, ultimately leading to a rupture (break-up) of the continent and the birth of new ocean basins (e.g., Buck, 1991, 2007). Depending upon the relative role of upwelling mantle flow and far-field forces in rift dynamics, rifting is conventionally considered to be either "active" (Sengör and Burke, 1978) or "passive" (McKenzie, 1978).

Despite significant progress in understanding of the rifting evolution from numerical (e.g., Burov and Poliakov, 2001; Huismans and Beaumont, 2003, 2008, 2011; Van Wijk and Blackman, 2005; Watremez et al. 2013; Brune et al., 2014; Brune, 2016; Brune et al., 2017; Le Pourhiet et al., 2017) and analogue modeling (e.g., Benes and Davy, 1996; Brun, 1999; 2002; Chemenda et al., 2002; Sokoutis et al., 2007; Bonini et al., 2007; Corti, 2008, 2009; Corti et al., 2011, 2013), many unanswered questions remain. Some unresolved problems are the rapid strain transfer from rift-bounding faults to narrow magmatic segments (Ebinger and Casey, 2001; Corti, 2008), the enigmatic coexistence of magmatic and amagmatic overlapping rift branches (Ebinger et al., 2000; Nyblade and Brazier, 2002; Ring, 2014), the cause of significant along-axis rift width variations (Zeyen et al., 1997; Corti et al., 2013), or the origin of along-strike tectonic/magmatic segmentation of volcanic margins (Geoffroy 2001, 2005). Most of these questions are directly or indirectly related to asymmetrical 3D features of the structural patterns and, as a result, require 3D models.

Recent technical and conceptual advances in numerical modeling have enlarged the possibility to investigate geodynamic processes with the help of 3D numerical experiments (e.g., Gerya and Yuen, 2007; Popov and Sobolev, 2008; Braun et al., 2008; Gerya, 2010; Thieulot, 2011; May et al., 2014, 2015). The results of 3D ultra-high resolution models that couple mantle/lithosphere system in a dynamically and rheologically consistent framework 
show that an upwelling mantle plume combined with far-field extension leads to the localization of continental extension along well-defined rift basins, thus reconciling the passive (external tectonic stresses) and active (plume-activated) rift concepts (Burov and Gerya, 2014; Koptev et al., 2015).

We follow-up on the study of Burov and Gerya (2014) with a series of numerical experiments of ascending mantle plume interacting with a rheologically realistic continental lithosphere subjected to ultra-slow far-field extension. Indeed, a number of geodetic studies now indicate that continental rifting initiates at extension rates of only a few millimeters per year (e.g., Calais et al., 1998; Saria et al., 2014; Birhanu et al., 2016). Our study focuses on the variations of plume-induced rifting style - mode of strain localization, deformation zone width, spatial location of break-up and spreading axes - as a function of variations in thermorheological properties of the continental lithosphere. We investigate a broad spectrum of thermo-rheological lithospheric profiles ranging from complete mechanical coupling to complete decoupling by varying either the lithology of the lower crust (wet quartzite and plagioclase flow laws, respectively) or the temperature at the Moho for a wet quartzite flow law. We also test the influence of varying the far-field extension rate and the mantle plume density.

In our previous works (Koptev et al., 2015, 2016), we have shown that the variations in the plume size and/or temperature have negligible effect on the principal output features of the models. Thus, here we intentionally focus on the analysis of thermo-rheological properties of the lithosphere and far-field tectonic forces.

We do not address the role of structural inheritance, which has been previously investigated by 2D simulations of continental rifting and breakup processes (e.g., Le Pourhiet et al., 2004; Huet et al., 2011; Chenin and Beaumont, 2013; Manatschal et al. 2015). Yet, recent 3D modeling studies of continental extension have demonstrated that complexities and 
multiphase tectonic evolution often attributed to inherited heterogeneities can naturally emerge from spontaneous 3D interactions (Brune et al., 2012; Le Pourhiet et al., 2012; Brune and Autin, 2013; Brune, 2014, 2016; Gerya, 2013; Liao and Gerya, 2014, 2015; Beniest et al., 2017; Le Pourhiet et al., 2017). Therefore, we believe that before studying the role of preexisting heterogeneities in $3 \mathrm{D}$, it is important to evaluate the complexity that can emerge spontaneously from the intrinsic dynamics of plume-induced continental rifting and breakup under slow far-field extension. 


\section{Numerical model description}

\section{1. $3 D$ model design}

\subsubsection{Spatial dimensions and resolution}

We produced the simulations presented in this contribution using viscous-plastic I3ELVIS code (Gerya and Yuen, 2007; Gerya, 2010). This code is based on conservative finite differences and a marker-in-cell technique (see Supplementary Methods for more details).

The regular rectangular model box used in this study consists of $297 \times 297 \times 133$ nodes (corresponding to dimensions of $1500 \times 1500 \times 635 \mathrm{~km}$ ) and offers spatial resolution of ca. $5 \times 5 \times 5 \mathrm{~km}$ per grid cell. These simulations require large computational efforts. At each timestep, the code solves a system of algebraic equations that comprises thirty million degree of freedom and advects a hundred million randomly distributed Lagrangian markers. The total model time of experiments varies between 40 and $100 \mathrm{Myr}$, representing 50,000 timesteps on average. Simulations were run on a SGI shared (NUMA) fat-node cluster with $2.8 \mathrm{Ghz}$ Intel Xeon CPU cores. Each simulation represents 5 years of CPU time in total.

\subsubsection{Internal model structure}

We impose a $30 \mathrm{~km}$-thick "sticky air" layer at the uppermost part of the model domain to approximate the upper surface of the crust as a free surface. The viscosity of the "sticky air" is $10^{18} \mathrm{~Pa} \mathrm{~s}$ and its density is $1 \mathrm{~kg} / \mathrm{m}^{3}$, according to optimal parameters established by Crameri et al. (2012). We use a vertically stratified continental lithosphere with an upper crust, lower crust, and lithospheric mantle lying on the upper mantle.

The total crustal thickness is $36 \mathrm{~km}$ and comprises two layers of $18 \mathrm{~km}$ each. The ductile rheology of the upper crust is of minor importance since the corresponding depth interval of 0-18 km is mainly dominated by rock type independent brittle failure (Byerlee, 
1978; Brace and Kohlstedt, 1980; Kohlstedt et al., 1995; Burov, 2011). Therefore, we employ a felsic upper crust described by wet quartzite rheology (Supplementary Table 1) in all experiments.

In contrast, the effective rheology of the lower crust is strongly controlled by temperature and lithology. Moreover, the rheological behavior of the lower crust, which controls the mechanical coupling within lithospheric layers and the integrated strength of the lithosphere (Burov and Diament, 1995), is known to influence the mode of continental rifting (e.g. Buck 1991; Burov and Poliakov, 2001, 2003; Buck, 2007; Gueydan et al., 2008), even in 3D (Le Pourhiet et al., 2017). In order to explore different levels of (de)coupling, we varied the temperature at the Moho for a wet quartzite lithology (Table 1). However, because this lithology does not permit to capture cases with strong coupling, we also performed a strongly coupled experiment (model 2, Table 1) using a strong mafic lower crust described by plagioclase rheology (Supplementary Table 1).

The ductile rheology of the mantle lithosphere (dry olivine flow law, Supplementary Table 1) is controlled by dry olivine dislocation and Peierls creeping flow, while the hot asthenospheric mantle (dry olivine flow law as well) deforms predominantly by diffusion creep (Evans and Goetze, 1979; Caristan, 1982; Karato and Wu, 1993; Durham et al., 2009). The initial depth of the lithosphere-asthenosphere boundary is $150 \mathrm{~km}$.

We initiate a mantle plume by seeding a temperature anomaly at the base of the model box (635 km). Following Burov and Gerya (2014) and Koptev et al. (2015, 2016), this initial anomaly is modeled as a hemisphere with a radius of $200 \mathrm{~km}$. In order to explore the sensitivity of rifting style to variations in the buoyancy of the mantle plume, we decrease the mantle plume density calculated from standard thermodynamic petrological models (Perple_X; Connolly, 2005) by $30 \mathrm{~kg} / \mathrm{m}^{3}$ in models 13-14 (Table 1). We assume that the 
mantle plume contains a small amount of water so that its deformation follows a wet olivine flow law (see Supplementary Table 1).

As mentioned above, we intentionally avoid any pre-imposed structuration within crust and lithospheric mantle. We address the readers Koptev et al. $(2015,2016)$ for the detailed analysis of the role of the inherited rheological discontinuities (cratonic blocks, suture zones).

\subsubsection{Initial temperature distribution and thermal boundary conditions}

The initial geotherm is piece-wise linear, with $0^{\circ} \mathrm{C}$ at the surface $(\leq 30 \mathrm{~km}$, the air), $500-800^{\circ} \mathrm{C}$ at the Moho (see Table 1 ), $1300^{\circ} \mathrm{C}$ at the lithospheric base and $1630^{\circ} \mathrm{C}$ at the bottom of the model domain $(635 \mathrm{~km}$ depth). The resulting adiabatic thermal gradient in the mantle is $0.5-0.7^{\circ} \mathrm{C} / \mathrm{km}$. The mantle plume has an initial temperature of $2000^{\circ} \mathrm{C}$, which corresponds to a 300 to $370^{\circ} \mathrm{C}$ temperature excess between the plume and the surrounding mantle. This relatively large temperature excess is consistent with seismic data showing the 20-40 km depression of the $410 \mathrm{~km}$ discontinuity beneath the eastern branch of the East African rift system in Kenya and Tanzania (Huerta et al., 2009) where low-velocity anomalies indicate the upper-mantle thermal structure related to the African superplume (Nyblade, 2011).

We use a constant temperature condition at the upper surface $\left(0^{\circ} \mathrm{C}\right)$ and at the bottom $\left(1630^{\circ} \mathrm{C}\right)$ of the model, and a thermal insulating boundary condition (i.e. zero conductive heat flux) to all vertical boundaries.

\subsubsection{Velocity boundary conditions}

We simulate weak tectonic forcing by applying a constant, time-independent, extension rate along the entire length of the right ("eastern") and left ("western") sides of the 
model domain. We use a half rate of extension of $3 \mathrm{~mm} / \mathrm{yr}$ for the reference experiment, a typical value for pre-break-up continental rifts affected by mantle upwellings, such as the Rio Grande and East African rifts (Buck, 2007; Stamps et al., 2008; Saria et al., 2014). We test the influence of this parameter by varying it within a range of 1.5 to $6 \mathrm{~mm} / \mathrm{yr}$ (see Table 1 ). We chose the upper limit in order to ensure that the resulting horizontal forces along the borders of the models are of the same order of magnitude as "ridge push" $\left(2-3 \times 10^{12} \mathrm{~N}\right.$ per unit length) and "slab pull" (4-6 × 10 ${ }^{12} \mathrm{~N}$ per unit length) forces (e.g. Parsons and Richter, 1980; Schellart, 2004). This ensures that we do not violate the far-field tectonic forces available within typical continental lithosphere in plate interiors (e.g., Forsyth and Uyeda 1975; Buck, 2006, 2007). We use free slip boundary conditions at the "northern" and "southern" sides of the models, which we do not subject to extension. Compensating vertical velocities along the upper and lower model boundaries are calculated on the basis of mass conservation within the model domain.

\subsection{Modeling procedure: Experiments and key variable parameters}

We tested 14 different experimental settings (Table 1) by varying four controlling parameters that characterize the properties of the lithosphere (lower-crustal rheology and Moho temperature), boundary conditions (extension half rate), and mantle plume density.

In the reference experiment (model 1), an initial temperature of $700^{\circ} \mathrm{C}$ at the Moho results in rheological decoupling between the upper crust and the lithospheric mantle. In contrast, model 2 shows strong rheological coupling due to the stronger (mafic) rheology imposed for the lower crust. Moho temperature from $500^{\circ} \mathrm{C}$ to $800^{\circ} \mathrm{C}$ (models 3-5) permits to investigate intermediate coupling cases. Models 6-8 illustrate the impact of the velocity boundary conditions: slower (1.5 and $2 \mathrm{~mm} / \mathrm{yr}$; models 6 and 7, respectively) and faster (6 $\mathrm{mm} / \mathrm{yr}$; model 8) far-field extension with respect to assumed in the reference model 1 (3 
$\mathrm{mm} / \mathrm{yr}$ ). Combined variations of Moho temperature and extensional velocity are represented by models 8-12. In model 13, Perple_X-derived density of the mantle plume is reduced by 30 $\mathrm{kg} / \mathrm{m}^{3}$ to investigate the effect of the plume chemical buoyancy. Model 14 combines a lighter mantle plume and faster far-field extension.

Before proceeding to the description of the results, we should note here that resolution tests were performed in order to assess the robustness of our results. The results presented in Supplementary Figure 1 show that a notable decrease in the resolution (up to $10 \mathrm{~km}$ per grid cell) leads to distributed small-offset faulting (Supplementary Figure 1a-c). On the contrary, the middle-resolution experiments $(7.5 \mathrm{~km}$ per grid cell) produce similar localization pattern as the one produced with a higher resolution used in our study $(5 \mathrm{~km}$ per grid cell, Supplementary Figure 1d-f). We conclude that the linear localized sub-parallel faults are robust model feature as they systematically appear independently of the size of the grid cell. The resolution of $5 \mathrm{~km}$ per cell adopted in the series of experiments presented is therefore optimal and further increasing the resolution would not change significantly the interpretation of the models. 


\section{Experimental results}

\subsection{Reference model 1}

For the chosen parameters, the reference model (Figures 1-3) produces a rapid mantle ascent as the plume material reaches the base of the lithosphere in 0.5 Myr. Surface topography first reacts by domal uplift (Figure 2a), soon after $(<3 \mathrm{Myr}$ ) replaced by subsidence and coeval initiation of series of linear, localized, and sub-parallel normal faults associated with long and narrow rifted basins (Figure 1a; Figure 2b). These faults merge into a localized, linear rift, which crosses the entire model domain in the direction perpendicular to the far-field extension, with considerable narrowing in its central part (Figure 1a). In crosssection, the model shows concentrated brittle strain in the upper crust underlain by a lower crust subjected to distributed ductile flow (Figure 3a).

As shown by Burov and Gerya (2014), this model indicates that a hot mantle upwelling allows for this strain localization within a laterally homogenous lithosphere subjected to weak far-field forcing. However, this does not lead to immediate lithospheric scale break-up: localized deformation is restricted to the brittle upper crust whereas the highstrength lithospheric mantle remains almost undeformed slowly flowing under applied external extension (Figure 3a).

Ductile flow in the lower crust leads to crustal boudinage within the central part of the model domain (see zoom inset of Figure 3d). In more details, as the lower crust rises, it appears to be harder to localize brittle deformation, which causes lateral migration of brittle upper-crustal strain towards adjacent undeformed areas (Figure 3b-d). This results in gradual in-sequence opening of the rift basin (Figure 1b; Figure 2c-f), which is bounded by active normal faults that are always located at the edge of the thinned and previously deformed crust (Figure 3b-d). 
The generated rift basin opens $\sim 3$ times faster than the imposed far-field extension rate: a $600-\mathrm{km}$ wide rift forms in less than $35 \mathrm{Myr}$ while the amount of passive extension applied at the boundaries is only $200 \mathrm{~km}$ (Figure 1b, Figure 3d). This confirms that, for plume-induced "active-passive" rifting, the active mantle upwelling is the main driver of rapid rifting.

Partial melting of almost whole plume head material at the early stage of the model evolution (Figure 3a-d) is consistent with geochemical data that suggest a deep mantle source for the pre-rift Oligocene flood basalts from the NW-Ethiopian plateau (e.g. Pik et al., 1999, 2006; Nelson et al., 2008, 2012; Halldórsson et al., 2014) and for mafic to ultramafic dykes and sills South China and Gairdner Dyke Swarm in Australia ( $825 \mathrm{Ma})$ preceding Rodinia rifting and break-up (e.g. Li, Z. et al., 1999; Li, X. et al., 2005; Wang et al., 2007).

The next stage of the system evolution starts at $~ 60-65$ Myr with the development of lithospheric scale faults associated with incipient and localized ascent of plume material through the lithosphere (Figure 3f). In contrast to the former stage, the entire lithosphere is now subjected to localized deformation, with necking and boudinage (Figure 3f) at two narrow and parallel areas located inside the rift valley that formed at the previous stage (Figure 1c). Their spatial position seems to be correlated with the location of the last melted portions of the plume head material (blue blobs on Figure 3e) before complete solidification. As the model evolves, one of these narrow rifts further develops into a spreading center while the other decays (Figure 1d; Figure 3g).

Thus, in the context of a laterally homogenous lithosphere, slow external extension and active mantle plume are not able to localize brittle deformation in the mantle lithosphere instantly. The high-strength lithospheric mantle remains almost undeformed over the first 60 Myr while highly localized brittle deformation concentrates in the upper crust, mechanically decoupled from the mantle by the ductile lower crust. This localized brittle deformation in the 
upper crust underlain by lower crust subjected to ductile flow corresponds to core complex mode of extension (see Buck, 1991). Upper-crustal deformation is localized along normal faults bounding a broad rift system with wide-spread in-sequence boudinage of the upper crust. Each localization event corresponds to the formation of a single core-complex before deformation migrates outward. Further model evolution shows a quick transfer to narrow rift mode (Buck, 1991) when the localized ascent of mantle plume material triggers strain localization along normal faults cutting through the whole lithosphere ( 60-65 Myr). Prebreak-up narrow rifting is followed by post-break-up spreading that initiates at $\sim 75 \mathrm{Myr}$. In this model, the spreading axis is shifted laterally from the center of the plume head.

\subsection{Model with plagioclase rheology of the lower crust (Model 2)}

In contrast to the reference model $\mathbf{1}$, model $\mathbf{2}$ (Figures 4,5 , and 6 ) is characterized by rheological coupling between the upper crust and the mantle lithosphere as a result of the stronger plagioclase rheology used for the lower crust (Table 1). This precludes ductile flow of lower-crustal material and leads to diffuse brittle deformation in the crust and the lithospheric mantle overlaying the plume head (Figure 6a). Further model evolution shows a gradual broadening of the area undergoing distributed deformation (Figure 6b-e). As a result, until about 30-40 Myr a large number of small-offset, parallel, and linear faults cover a 1000 km-wide dome of slightly elevated ( 400 m) topography (Figure 4a; Figure 5a).

Burov and Gerya (2014) showed that ultra-slow tectonic stretching of the continental lithosphere in the absence of active mantle upwelling results in broadly distributed smalloffset parallel faults, which are not localized within any particular zone (see also Supplementary Figure 2), and that in the same far-field tectonic context, the simultaneous impingement of active mantle plume leads to progressive focusing and amplification of localized non-axisymmetric deformation and to the development of major large-offset highly 
localized faults. Our results show that this rapid localization of the deformation at the surface only occurs when the lower crust can flow (see Section 3.1). When the lower crust is coupled to the lithospheric mantle the initial extension phase is not as focused as in Burov and Gerya (2014). Instead a first phase of distributed normal faulting (Figure 4a) reassembling the deformation of "no-plume" experiment by Burov and Gerya (2014) precedes the plumeinduced break-up.

Similarly to reference model $\mathbf{1}$, the next stage of the system development $(\sim 50-55$ Myr) shows localized deformation along two parallel zones (Figure $4 b-c$ ) marked by narrow topographic depressions (Figure 5b-c) underlaid by localized plume ascent (Figure 6f). Only one of these narrow rifts evolves into a spreading center (Figure 4d; Figure 5d-f; Figure 6g) whereas the other aborts, despite an apparent higher level of initial maturity (Figure 6f). It is noteworthy that the hot plume material does not produce uplift along the future break-up axis uniformly (see compositional distribution at $70 \mathrm{Myr}$ on Figure 7). A vertical cross-section along-strike the future line of break-up shows that the solidified mantle plume remains attached to the lithospheric base in its central part, whereas segments on either side show uplift and decompression melting (Figure 7d). These localized melting zones rise through the lithosphere up to Moho depth and lead to development of separated crustal magma reservoirs feeding volcanic centers along future "passive" margin.

The simultaneous distributed deformation in the crust and the mantle lithosphere during the initial stage of the model evolution contrasts greatly with the decoupled model. Brittle strain is spread over a broad region subject to the thermal influence of the mantle plume. In contrast to reference model 1 where the opening of the rift basin occurs by lateral migration of localized upper-crustal strain (Figure 3a-e), here the broadening of the rift zone occurs (Figure 6a-e) as a result of the lateral flow of the hot plume material within the lower part of the mantle lithosphere. As a result, strain accumulates predominately in the central part 
of the box, which favors a quasi-centered position of the narrow rift during subsequent model stages. This model therefore predicts that, in a rheologically coupled lithosphere, initial wide rifting is followed by narrow rifting localized at the location of maximum cumulative deformation, close to the plume source center. On the contrary, the in-sequence core complex extension mode in reference model 1 does not favor a particular location for narrow rift localization, which appears to be controlled by complex internal processes within the deep mantle plume. In this case, the final position of the narrow rift/spreading axis can be considerably shifted with respect to the area of initial plume impingement.

\subsection{Dependence of initial rift width and final break-up position on Moho}

\section{temperature}

In order to study different degrees of the rheological (de)coupling of the lithosphere, we performed a series of models with different temperatures at Moho interface (models 1, 35).

Similarly to reference model $\mathbf{1}$ (temperature at Moho depth of $700^{\circ} \mathrm{C}$ ), models $\mathbf{4}$ and $\mathbf{5}$ (Moho temperature of $600^{\circ} \mathrm{C}$ and $800^{\circ} \mathrm{C}$, respectively) show localized brittle deformation in the upper crust soon after ( $\sim 3 \mathrm{Myr})$ mantle plume impingement at the base of the lithosphere (Figure $8 b-d)$. On the contrary, a colder crustal geotherm $\left(500^{\circ} \mathrm{C}\right.$ at Moho interface, model 3) results in a wide $(\sim 500 \mathrm{~km})$ zone of highly distributed brittle strain (Figure $8 \mathrm{a})$. Decreasing Moho temperature leads to increasing lower-crustal strength. As a result, the area of brittle upper-crustal deformation widens from $100 \mathrm{~km}$ to $200-300 \mathrm{~km}$ then $500 \mathrm{~km}$ with decreasing of Moho temperature from $800^{\circ} \mathrm{C}$ to $500^{\circ} \mathrm{C}$ (models $\mathbf{5}, \mathbf{1 , 4}$ and $\mathbf{3}$, respectively, see Figure 8).

A systematic analysis of the models with different combinations of initial crustal geotherm and applied far-field extension rate (models 1, 4-6; 8-12; Figure 9; Supplementary Table 2) shows that this trend persists regardless of the far-field velocities applied: increasing 
the Moho temperature from $600^{\circ} \mathrm{C}$ to $800^{\circ} \mathrm{C}$ leads to decreasing the rift width from $425 \mathrm{~km}$ to $150 \mathrm{~km}$ for the fastest half-velocity $(6 \mathrm{~mm} / \mathrm{yr})$ and from $175 \mathrm{~km}$ to $75 \mathrm{~km}$ for the slowest one $(1.5 \mathrm{~mm} / \mathrm{yr})$.

Further evolution of the model with a relatively hot geotherm $\left(800^{\circ} \mathrm{C}\right.$ at Moho, model 5, Figure 10d) shows opening of the rift basin due to lateral migration of localized uppercrustal deformation similar to the core complex extension mode of reference model $1\left(700^{\circ} \mathrm{C}\right.$ at Moho; Figures 1-3; Figure 10c). On the contrary, the model with the coldest Moho temperature $\left(500^{\circ} \mathrm{C}\right.$, model 3, Figure $\left.10 \mathrm{a}\right)$ shows a gradual broadening of the area experiencing distributed brittle strain, up to a width of $\sim 750 \mathrm{~km}$ at $20 \mathrm{Myr}$. As in the model with a mafic lower crust (model 2, Figure 4-6), this deformation mode can be classified as wide rifting. The lithosphere remains slightly decoupled even with the coldest geotherm, thus, restricting brittle deformation to the upper crust and keeping lithospheric mantle undeformed (Figure 8a; Figure 10a). Model $4\left(600^{\circ} \mathrm{C}\right.$ at Moho depth) displays an intermediate extension mode (Figure 10b): the highest brittle strain rate is concentrated along normal faults bounding wide rift valley but distributed internal deformation continues within the basin.

The rate of rift basin opening seems to be controlled by the lateral spreading of mantle plume material. In the case of the hottest geotherm $\left(800^{\circ} \mathrm{C}\right.$ at Moho; model 5), the plume material penetrates profoundly into the lithospheric mantle, which limits its lateral flow. This is reflected in the relatively narrow (200 km-wide at $20 \mathrm{Myr}$ ) rift valley formed above (Figure 10d). On the contrary, a colder lithospheric geotherm $\left(600-700^{\circ} \mathrm{C}\right.$ at Moho; models 1,4$)$ prevents the vertical penetration of the plume head but favors its lateral spreading. This results in considerably broader (350-500 km-wide at $20 \mathrm{Myr}$ ) rift basins (Figure 10b-c). Decreasing Moho temperature to $500^{\circ} \mathrm{C}$ (model 3) leads to further increasing the rift basin width, up to $\sim 750 \mathrm{~km}$ (Figure 10a). This results from wider lateral spreading of the plume material, together with a change of extension mode to wide rifting. 
Thus, the width of initially localized deformation appears to be governed by the degree of rheological (de)coupling between the brittle upper crust and the lithospheric mantle, whereas the subsequent opening of the rift basin is controlled by lateral flow of the mantle plume, which, in turn, is conditioned by the lithospheric geotherm (Supplementary Figure 3).

As mentioned above (see Section 3.1-3.2), both the core complex and wide rift modes of extension are condemned to be succeeded by narrow rifting and spreading.

In case of reference model $1\left(700^{\circ} \mathrm{C}\right.$ at Moho; Figure $\left.11 \mathrm{c}\right)$, the spatially decentered narrow rifts are linked to the last melted fragments remaining inside the mantle plume material before its complete solidification (see also Figure 3e-f). Meanwhile, due to its hotter lithospheric geotherm $\left(800^{\circ} \mathrm{C}\right.$ at Moho), model 5 shows a transition to narrow rift mode before complete plume solidification: the remaining fragments of the melted plume material are involved in its localized ascent along two axes shifted symmetrically with respect to the center of the plume head (Figure 11d). They both later evolve into spreading axes (Figure 13c) in contrast to reference model $\mathbf{1}$ where only one of the narrow rifts survives (Figure 1d; Figure 3g; Figure 13a).

Experiments with a colder Moho temperature $\left(500-600^{\circ} \mathrm{C}\right.$; models 3-4) result in a (quasi)central position of the localized narrow rifts (Figure 11a-b). This appears to be typical for models characterized by a (quasi)“wide rift" mode of initial crustal deformation (see also model 2 with mafic lower crust; Figure 6). The gradual broadening of diffuse brittle deformation leads to strain accumulation within the central part of the model domain resulting in a (quasi)centered position of the newly formed narrow rifts.

Thus, the initial mode of crustal deformation is crucial for the spatial location of future narrow rifts and spreading centers. In the case of core complex-like extension, the break-up location is likely to be shifted with respect to the area of initial plume impingement. On the 
contrary, a wide rift mode results in narrow rifting and break-up above the plume head center (Supplementary Figure 3).

The onset of the narrow rifting stage is triggered by the isolated uplift of hot plume material along narrow stretched zones (Figure 3f; Figure 6f). Figure 12 summarizes the timing for initiation of this localized plume ascent. It increases linearly from $50 \mathrm{Myr}$ through 65-80 Myr to $95 \mathrm{Myr}$ with decreasing Moho temperature from $800^{\circ} \mathrm{C}$ to $500^{\circ} \mathrm{C}$ (models $5, \mathbf{1}, 4$ and 3, respectively; see white triangles and squares on Figure 12). However, the model with a mafic lower crust $\left(700^{\circ} \mathrm{C}\right.$; model 2 ; see grey square on Figure 12$)$ shows a rapid transition to narrow rifting $(55 \mathrm{Myr})$, considerably faster than in model $3\left(500^{\circ} \mathrm{C}\right)$, which is similar in terms of initial deformation mode (wide rift). Thus, at constant stretching rate, the timing of lithospheric break-up is controlled by the lithospheric geotherm rather than by the mode of initial crustal deformation. Yet, increasing extension rate (models 8; black triangle on Figure 12) significantly decrease the time between plume impact and break-up. Doubling the extension rate from $3 \mathrm{~mm} / \mathrm{yr}$ (model 1 ) to $6 \mathrm{~mm} / \mathrm{yr}$ (model 8) indeed reduces the time to onset of narrow rifting time (65 Myr and 20 Myr, respectively), while a reduction of the half rate from 3 to $2 \mathrm{~mm} / \mathrm{yr}$ (model 7) results in considerable prolongation of the initial stage of deformation (up to $90 \mathrm{Myr}$ ). An important consequence is that, for "active-passive" rifting, far-field extension rates cannot be directly derived from geological observations of rift basin opening because of the important role played by active mantle upwelling in the force balance.

\subsection{Spatial position of narrow rifts/spreading axis}

As mentioned above, narrow rifting tends to localize directly above the plume head center in models with relatively high rheological coupling between the upper crust and the mantle lithosphere. On the contrary, a rheologically decoupled lithosphere favors considerable 
$(\sim 100 \mathrm{~km})$ shift of the break-up center(s) with respect to the area of initial plume impingement.

Additional experiments that combine a rheologically decoupled continental lithosphere with faster far-field extension (models 8, 14) and decreased plume density (models 13, 14), result in more complex break-up configurations (Figure 13d-f). Models with faster extension rate (models $\mathbf{8}, \mathbf{1 4}$ ) shows two en echelon overlapping spreading zones interconnected by a $>200 \mathrm{~km}$ long orthogonal transfer zone (Figures 13d,f) that could be a precursor structure for oceanic transform faults observed in nature. Model 13, with a lighter mantle plume together with the reference far-field extension value (Figure 13e) evolves into an interesting pattern with an "eastern" and overlapping "western" elongated break-up zone that resemble the two branches observed in the East African rift around the Tanzanian craton (Figure 14a).

These results illustrate that the geometry of the plume-induced rifting/break-up pattern can be strongly variable and asymmetric even in the absence of inherited crustal/lithospheric heterogeneities. The weakening effect (i.e. plastic strain softening (e.g. Huismans and Beaumont, 2003), see Supplementary Methods) amplify initial small perturbations that are introduced by the randomly distributed markers, thus, resulting in the asymmetry that seems to be an intrinsic characteristic of plume-induced rifting/spreading process that develops spontaneously from initially symmetrical plume-lithosphere geometry. The final position of the continental break-up zone(s) is likely to be offset with respect to the plume impingement and, consequently, does not necessarily coincide with the area of pre-rift uplift and magmatism. 


\section{Discussion}

\subsection{Two-stage continental rifting}

Rapid transfer from extensional deformation on normal faults bounding the rift valley to localized strain accommodated within a narrow zone associated with volcanic activity in the rift valley has been argued for in the Main Ethiopian rift (Ebinger and Casey, 2001). Present-day strain accommodation along narrow magmatic Wonji segments may be related to magma-assisted rifting by repeated magma intrusion (Kendall et al., 2005, 2006). Alternatively, this strain transfer from border faults to Wonji segments may be controlled either by rift kinematics variations (Boccaletti et al., 1999) or by obliquity of far-field extension to the trend of the rift (Corti, 2008, 2009).

Rheologically decoupled model $\mathbf{1}$, however, shows that the rapid transition from wide rift to strain localization along narrow zones can simply result from plume uplift triggering a transition from in-sequence crustal scale core complex to narrow rift mode of deformation (Figure 1c; Figure 3f). Models show that this transition takes place considerably earlier $(\sim 15$ Myr) than the penetration of melted plume material in the crust (Figure 1d; Figure 3g) and does not require pre-defined oblique heterogeneities or variations in rift kinematics. Consequently, the polyphase evolution of the Main Ethiopian rift may be explained in the framework of self-induced processes resulting from the interaction between a mantle plume and a homogeneous continental lithosphere under constant far-field extension.

Model 2 (strongly coupled lithosphere) where wide rifting is followed by the formation of narrow rift can be compared with the southern Basin and Range, where the Gulf of California (Henry, 1989; Lizarralde et al., 2007; Ferrari et al., 2013) and Rio Grande rifts (Morgan et al., 1986; Baldridge et al., 2006) cut through an older network of distributed normal faults (Buck, 1991). Similar migration of fault activity through time can be also observed across the East Shetland Basin in the northern North Sea (Cowie et al., 2005). 


\subsection{Along-strike and across-strike segmentation}

Along-strike and across-strike asymmetry of break-up patterns appears to be intrinsic characteristic of most of our 3D experiments.

Model 2 shows non-uniform ascent of plume material along the future break-up center, which results in the development of separated magma chambers (Figure 7). Localized crustal magma reservoirs and their sources in the mantle have been inferred from magnetic fabric studies of magma flow in the East Greenland dyke swarm (Callot et al., 2001; Callot and Geoffroy, 2004). The along-strike tectono-magmatic segmentation of volcanic "passive" margins was interpreted to result from small-scale convection (Geoffroy, 2001, 2005; Callot et al., 2002; Gac and Geoffroy, 2009) resembling localized buoyancy-driven mantle flow, as proposed at the slow-spreading Mid-Atlantic Ridge (Lin et al., 1990). Model 2 shows that localized crustal zones of magma storage may develop as a result of self-induced spatial irregularities along-strike of a plume ascent channelized by localized crustal thinning, in a process that does not require pre-defined (sub)lithospheric density and/or thermal heterogeneities.

This non-uniform localized plume uplift can also reconcile the geophysical and geochemical evidence of a mantle plume and of the time progression of magmatism onset, when it is not consistent with plate motion. For example, the High Lava Plains (western part of Yellowstone hot spot track) progresses to the northwest over time in a direction that is not consistent with North American plate motion (Jordan et al., 2004; Meigs et al., 2009; Wagner et al., 2010). Model 2, with along-strike sinking of the plume apex from $35 \mathrm{~km}$ to $70 \mathrm{~km}$ (Figure 7d), provides a scenario that explains such time-progressive tracks of plume-related volcanism solely in terms of plume-lithosphere interaction without requiring the apparent plume track to align with plate motion. 
Faster localized uplift of the plume material at the distal point from the plume center is consistent with the timing of magmatic and tectonic events in the South Atlantic where seafloor spreading propagated northward up to the Tristan da Cunha hot-spot (Franke et al., 2013).

Across-strike segmentation is represented in our models by complex asymmetric systems characterized by various velocities of plume material uplift along different localized axes leading to contrasting rifting. The East African rift system can be considered as a natural example of asymmetrical continental rifts that develop in the context of plume-lithosphere interaction (Figure 14a-b). The simultaneous development of amagmatic and magmatic rift branches observed at opposite sides of the Tanzanian craton has been interpreted to result from the interaction of a plume with a craton (Koptev et al., 2016). Yet, the more simple and initially symmetrical model 14 (Figures 13f; Figure 14c-d) also reproduces a setting that bears similarities with the central East African rift without requiring a laterally heterogeneous lithosphere or an ad-hoc asymmetrical plume position with respect to a craton (Koptev et al., 2015). Another simple setup (model 13, Figures 13e) results in a final break-up pattern that matches well that of the central East African rift system: a straightened eastern branch and curved western branch propagating further to south into the Malawi rift (Figure 14a).

It is generally accepted that the geometry of the rifting/break-up pattern should be largely controlled either by pre-existing crustal and/or lithospheric heterogeneities (e.g., Ring, 1994; Corti et al., 2007; Bonini et al., 2007; Guillou-Frottier et al., 2012) or by the spatial position of hot mantle material ponding at the lithosphere-asthenosphere boundary with respect to lithospheric heterogeneities (Burov and Gerya, 2014; Koptev et al., 2016). Our models, however, generate spatial complexity similar to that observed at natural rifts without requiring that preexisting crustal or lithospheric structures control rift initiation and development. 


\subsection{General discussions}

Buck (1991) classifies the extension of continental lithosphere into three modes: narrow rift, wide rift, and core complex. A high-strength lithospheric mantle causes localized brittle deformation and the formation of a narrow rift. On the contrary, a ductile sub-Moho mantle leads to wide rifting or core complex modes of extension (Buck, 1991; Brun, 1999, 2002; Gueydan et al., 2008). Here we show that extension of a continental lithosphere with a high-strength uppermost mantle can initially result in both wide rift and core complex crustal deformation modes. Ultra-slow far-field extension applied to a homogenous lithosphere does not appear to be sufficient for propagation of large faults into the lithospheric mantle. As a result, during initial stage of extension, deformation concentrates in the crust with diffuse brittle strain in both upper and lower crust (wide rift mode) or localized brittle deformation in the upper crust underlain by lower crust subjected to ductile flow (core complex mode). Further extension and/or localized ascent of hot plume material results in concentrated deformation that eventually crosscuts the whole lithosphere and marks the transition to narrow rifting. Previous models assumed considerably larger far-field forcing (compared to the ultra-slow extension applied here, consistent with geodetic observations of present-day rifting) and/or pre-imposed lithospheric weaknesses. As a result, they lead to fast strain localization in the brittle sub-Moho mantle so that the initial stage of crustal extension observed here is absent. In contrast, our experiments predict a long (up to 100 Myr) stage of extensional deformation in the crust, either in wide rift or core complex mode, before strain localization into a narrow rift. In our models, the thermal impact of the upwelling plume material under ultra-slow extension determines crustal strain localization within a laterally homogenous lithosphere, as also proposed by Burov and Gerya (2014). However, plumeinduced perturbations are not sufficient for faulting to propagate through the high-strength lithospheric mantle. As a result, the narrow rift-like continental break-up at the final stage of 
model development is preceded by a long-lasting stage of wide rifting, possibly with the development of in-sequence core complex structures, depending on the rheology of the crust. The Basin and Range and the Main Ethiopian Rift may be natural examples of regions that have went through those two modes of extension, with narrow rift propagation following either distributed crustal extension (wide rift mode) or localized faulting at the boundaries of wide rift depression (core complex mode). The evolution of "passive" margin magmatism where pre-break-up volcanism over a large area (up to $10^{6} \mathrm{~km}$ in case of the NorthAtlantic/Labrador-Baffin system) predates syn-breakup magmatic activity concentrated at the continent-ocean boundary (Geoffroy, 2001; Geoffroy et al., 2015), is also consistent with this two-stage development.

Numerous examples have proven that the degree of plate coupling have major implications on the deformational processes in extensional and compressional systems (e.g. Beaumont and Quinlan, 1994; Brun, 2002; Willingshofer et al., 2013; Jammes and Huismans, 2012; Vogt et al., 2017; Le Pourhiet et al., 2017). In our models, the style of initial crustal deformation (in-sequence core complex or synchronous distributed faulting) is controlled by the rheological coupling between the upper crust and the lithospheric mantle. When a weak lower crust acts as a decoupling layer, brittle strain in the upper crust is strongly localized due to compensating ductile flow of lower-crustal material (core complex mode). On the contrary, a strong lower crust that efficiently couples the upper crust to the mantle lithosphere leads to distributed brittle deformation in both the upper and lower crust (wide rift mode). A variety of intermediate cases is possible. For instance, a lowering of the temperature at the bottom of a weak felsic lower crust expectedly leads to a gradual increase of the width of core complexlike deformation area, which results in wide rift mode for the coldest geotherm. These results are consistent with inferences derived from analogue modeling (Brun, 2002). 
We observe in our models that the location of the final narrow rift, i.e. the breakup location, is governed by the mode of initial crustal deformation. A strong lower crust favors continental break-up coincident with the region of maximum cumulative deformation above the plume head center. On the contrary, a weak lower crust usually results in break-up that is laterally shifted with respect to the initial plume position. In this case, strain localization in the lithospheric mantle is controlled by partial melting, crystallization fractionation, and other processes within the mantle plume ponding lithosphere-asthenosphere boundary. This results in a significant offset between the area of initial surface response to the plume impingement and the final axis of continental break-up.

Most of our 3D experiments, as well as other 3D experiments published in the last 10 years (Brune et al., 2012; Le Pourhiet et al., 2012; Brune and Autin, 2013; Gerya, 2013; Liao and Gerya, 2014, 2015; Brune et al., 2014, 2017; Le Pourhiet, 2017), produce self-induced temporal and spatial (across-strike and along-strike) break-up irregularities that were only produced in 2D using very strong lateral mechanical heterogeneities. Without dismissing that lithological heterogeneities are present in the crust and the lithosphere, our work provides new elements to evaluate their actual importance in the dynamics of continental rifting. 


\section{Conclusions}

Despite controversy concerning causes for continental break-up that persists between far-field lithospheric extension and mantle (super)plume(s) (Anderson, 1994; White and McKenzie, 1995; Storey, 1995; Courtillot et al., 1999; Anderson, 2000; Dalziel et al., 2000; Foulger and Hamilton, 2014), our previous studies (Burov and Gerya, 20014; Koptev et al., 2015,2016 ) have permitted to reconcile the active and passive models.

The present study identifies the importance of the vertical stratification of lithospheric rheology on the pattern and evolution of continental rifting under the presence of a plume and weak far-field extension.

1. Continental rifting in our models always occurs in two stages, irrespective of the initial rheological stratification of the lithosphere: an early crustal rifting stage and a later lithospheric necking (breakup) stage. The crustal rifting stage influences the lithospheric breakup stage because it pre-structures the crust differently.

2. A rheologically decoupled lithosphere (i.e. with a weak lower crust) favors core complex extension mode with localized upper-crustal brittle strain while the lower crust is subject to compensating ductile flow. On the opposite, rheological coupling between the upper crust and the mantle lithosphere leads to diffuse brittle deformation (wide rift mode). Thus, plume-induced initial strain localization is not only restricted to the brittle upper crust but also requires the lithosphere which is rheologically decoupled by a ductile lower crust.

3. Plume-induced thermal perturbations are not sufficient for rapid faulting through high-strength lithospheric mantle. We observe that concentrated deformation along narrow faults zones cutting through the whole lithosphere is preceded by long-term (up to 100 Myr long) stage of wide rift or core complex-like crustal extension. In the models, the transition to the subsequent narrow rift stage is triggered by localized ascent of plume material. Narrow rift localization following core-complex mode of extension seems to be governed by complex 
processes within the deep mantle plume, thus resulting in break-up axes considerably shifted with respect to the area of initial plume impingement. On the opposite, wide rifting favors more a predictable final position of the break-up axis close to the area of maximum cumulative deformation above the plume source center.

4. Most of the models with a rheologically decoupled lithosphere show a highly asymmetrical narrow rifting/spreading system that develops spontaneously from symmetrical and laterally homogenous experimental setups. This self-induced asymmetry seems to be an intrinsic characteristic of the rifting and break-up processes associated with the plumelithosphere interaction under weak and constant far-field extension.

Acknowledgements. We thank two anonymous reviewers for helpful comments on this manuscript. This study is co-funded by the Advanced ERC Grant 290864 RHEOLITH to E. Burov and A. Koptev, by a U.S. National Science Foundation grant EAR-0538119 to E. Calais. The numerical simulations were performed on the ERC-funded SGI Ulysse cluster of ISTEP. 


\section{REFERENCES}

Anderson, D.L., 1994. Superplumes or supercontinents? Geology 22, 39-42.

Anderson, D.L., 2000. The thermal state of the upper mantle; no role for mantle plumes. Geophysical Research Letters 27, 3623-3626.

Baldridge, W.S., Keller, G.R., Haak, V., Wendlandt, E., Jiracek, G.R., Olsen, K.H., 2006. The Rio Grande rift. Developments in Geotectonics 25, 233-XIII.

Beaumont, C., Quinlan, G., 1994. A geodynamic framework for interpreting crustal-scale seismic-reflectivity patterns in compressional orogens. Geophysical Journal International 116, $754-783$

Benes, V., Davy, P., 1996. Modes of continental lithospheric extension: experimental verification of strain localization processes. Tectonophysics $254,69-87$.

Beniest, A., Koptev, A., Burov, E., 2017. Numerical models for continental break-up: Implications for the South Atlantic. Earth and Planetary Science Letters 461, 176-189.

Birhanu, Y., Bendick, R., Fisseha, S., Lewi, E., 2016. GPS constraints on broad scale extension in the Ethiopian Highlands and Main Ethiopian Rift. Geophysical Research Letters $43,1-8$.

Boccaletti, M., Bonini, M., Mazzuoli, R., Trua, T., 1999. Plio-Quaternary volcanotectonic activity in the northern sector of the Main Ethiopian Rift: Relationships with oblique rifting. Journal of African Earth Sciences 29, 679-698.

Bonini, M., Corti, G., Ventisette, C.D., Manetti, P., Mulugeta, G., Sokoutis, D., 2007. Modelling the lithospheric rheology control on the Cretaceous rifting in West Antarctica. Terra Nova 19, 360-366. 
Brace, W.F., Kohlstedt, D.L., 1980. Limits on lithospheric stress imposed by laboratory experiments. Journal of Geophysical Research: Solid Earth 85, 6248-6252.

Braun, J., Thieulot, C., Fullsack, P., DeKool, M., Beaumont, C., Huismans, R.S., 2008. DOUAR: A new three-dimensional creeping flow numerical model for the solution of geological problems. Physics of the Earth and Planetary Interiors 171, 76-91.

Brun, J.P., 1999. Narrow rifts versus wide rifts: inferences for mechanics of rifting from laboratory experiments. Philosophical Transactions of the Royal Society of London 357, 695712.

Brun, J.P., 2002. Deformation of the continental lithosphere: Insights from brittle-ductile models. Geological Society, London, Special Publications 200, 355-370.

Brune, S., 2014. Evolution of stress and fault patterns in oblique rift systems: 3-D numerical lithospheric-scale experiments from rift to breakup. Geochemistry, Geophysics, Geosystems $15,3392-3415$.

Brune, S., 2016. Rifts and Rifted Margins: A Review of Geodynamic Processes and Natural Hazards. Plate Boundaries and Natural Hazards 219, 13.

Brune, S., Autin, J., 2013. The rift to break-up evolution of the Gulf of Aden: Insights from 3D numerical lithospheric-scale modelling. Tectonophysics 607, 65-79.

Brune, S., Heine, C., Clift, P.D., Pérez-Gussinyé, M., 2017. Rifted margin architecture and crustal rheology: Reviewing Iberia-Newfoundland, central South Atlantic, and South China sea. Marine and Petroleum Geology 79, 257-281.

Brune, S., Heine, C., Pérez-Gussinyé, M., Sobolev, S.V., 2014. Rift migration explains continental margin asymmetry and crustal hyper-extension. Nature Communications 5. 
Brune, S., Popov, A.A., Sobolev, S.V., 2012. Modeling suggests that oblique extension facilitates rifting and continental break-up. Journal of Geophysical Research: Solid Earth 117, B8.

Buck, W.R., 1991. Modes of continental extension. Journal of Geophysical Research 96, 20161-20178.

Buck, W.R., 2006. The role of magma in the development of the Afro-Arabian Rift System. Geological Society, London, Special Publications 259, 43-54.

Buck, W.R., 2007, Dynamic processes in extensional and compressional settings - the dynamics of continental breakup and extension. In Treatise on Geophysics 6, Crust and Lithosphere Dynamics, edited by A. B. Watts, 335-376, Elsevier, New York.

Burov, E., 2011. Rheology and strength of the lithosphere. Marine and Petroleum Geology $28,1402-1443$.

Burov, E.B., Diament, M., 1995. The effective elastic thickness (Te) of continental lithosphere: What does it really mean? Journal of Geophysical Research: Solid Earth 100, 3905-3927.

Burov, E., Gerya, T., 2014. Asymmetric three-dimensional topography over mantle plumes. Nature 513, 85-103.

Burov, E., Poliakov, A., 2001. Erosion and rheology controls on synrift and postrift evolution: Verifying old and new ideas using a fully coupled numerical model. Journal of Geophysical Research: Solid Earth 106, 16461-16481.

Burov, E., Poliakov, A., 2003. Erosional forcing of basin dynamics: new aspects of syn-and post-rift evolution. Geological Society, London, Special Publications 212, 209-223.

Byerlee, J.D., 1978. Friction of rocks. Pure and Applied Geophysics 1, 6. 
Calais, E., Lesne, O., Déverchère, J., San'kov, V., Lukhnev, A., Miroshnitchenko, A., Buddo, V., Levi, K., Zalutzky, V., Bashkuev, Y., 1998. Crustal deformation in the Baikal Rift from GPS measurements. Geophysical Research Letters 25, 4003-4006.

Callot, J.P., Geoffroy, L., 2004. Magma flow in the East Greenland dyke swarm inferred from study of anisotropy of magnetic susceptibility: magmatic growth of a volcanic margin. Geophysical Journal International 159, 816-830.

Callot, J.P., Geoffroy, L., Aubourg, C., Pozzi, J.P., Mege, D., 2001. Magma flow directions of shallow dykes from the East Greenland volcanic margin inferred from magnetic fabric studies. Tectonophysics 335, 313-329.

Callot, J.P., Geoffroy, L., Brun, J.P., 2002. Development of volcanic passive margins: Threedimensional laboratory models. Tectonics 21, 6 .

Caristan, Y., 1982. The transition from high temperature creep to fracture in Maryland diabase. Journal of Geophysical Research: Solid Earth 87, 6781-6790.

Chemenda, A., Deverchere, J., Calais, E., 2002. Three-dimensional laboratory modelling of rifting: application to the Baikal Rift, Russia. Tectonophysics 356, 253-273.

Chenin, P., Beaumont, C., 2013. Influence of offset weak zones on the development of rift basins: Activation and abandonment during continental extension and breakup. Journal of Geophysical Research: Solid Earth 118, 1698-1720.

Connolly, J.A.D., 2005. Computation of phase equilibria by linear programming: a tool for geodynamic modeling and its application to subduction zone decarbonation. Earth and Planetary Science Letters 236, 524-541.

Corti, G., 2008. Control of rift obliquity on the evolution and segmentation of the main Ethiopian rift. Nature Geoscience 1, 258-262. 
Corti, G., 2009. Continental rift evolution: from rift initiation to incipient break-up in the Main Ethiopian Rift, East Africa. Earth-Science Reviews 96, 1-53.

Corti, G., Calignano, E., Petit, C., Sani, F., 2011. Controls of lithospheric structure and plate kinematics on rift architecture and evolution: An experimental modeling of the Baikal rift. Tectonics 30, 3 .

Corti, G., Iandelli, I., Cerca, M., 2013. Experimental modeling of rifting at craton margins. Geosphere 9, 138-154.

Corti, G., van Wijk, J., Cloetinhg, S., Morley, C.K., 2007. Tectonic inheritance and continental rift architecture: Numerical and analogue models of the East Arfican Rift system. Tectonics 26, TC6006.

Courtillot, V., Jaupart, C., Manighetti, I., Tapponnier, P., Besse, J., 1999. On causal links between flood basalts and continental breakup. Earth and Planetary Science Letters 166, 177195.

Cowie, P.A., Underhill, J.R., Behn, M.D., Lin, J., Gill, C.E., 2005. Spatio-temporal evolution of strain accumulation derived from multi-scale observations of Late Jurassic rifting in the northern North Sea: A critical test of models for lithospheric extension. Earth and Planetary Science Letters 234, 401-419.

Crameri, F., et al., 2012. A comparison of numerical surface topography calculations in geodynamic modelling: an evaluation of the 'sticky air' method. Geophysical Journal International 189, 38-54.

Dalziel, I.W., Lawver, L.A., Murphy, J.B., 2000. Plumes, orogenesis, and supercontinental fragmentation. Earth and Planetary Science Letters 178, 1-11. 
Durham, W.B., Mei, S., Kohlstedt, D.L., Wang, L., Dixon, N.A., 2009. New measurements of activation volume in olivine under anhydrous conditions. Physics of the Earth and Planetary Interiors $172,67-73$.

Ebinger, C.J., Yemane, T., Harding, D.J., Tesfaye, S., Kelley, S., Rex, D.C., 2000. Rift deflection, migration, and propagation: Linkage of the Ethiopian and Eastern rifts, Africa: Geological Society of America Bulletin 112, 163-176.

Ebinger, C.J., Casey, M., 2001. Continental breakup in magmatic provinces: An Ethiopian example. Geology 29, 527-530.

Evans, B., Goetze, C., 1979. Temperature variation of hardness of olivine and its implication for polycristalline yield stress. Journal of Geophysical Research: Solid Earth 84, 5505-5524.

Ferrari, L., López-Martínez, M., Orozco-Esquivel, T., Bryan, S.E., Duque-Trujillo, J., Lonsdale, P., Solari, L., 2013. Late Oligocene to Middle Miocene rifting and synextensional magmatism in the southwestern Sierra Madre Occidental, Mexico: The beginning of the Gulf of California rift. Geosphere GES00925-1.

Forsyth, D., Uyeda, S., 1975. On the relative importance of the driving forces of plate motion. Geophysical Journal International 43, 163-200.

Foulger, G.R., Hamilton, W.B., 2014. Earth science: Plume hypothesis challenged. Nature $505,618-618$.

Franke, D., 2013. Rifting, lithosphere breakup and volcanism: Comparison of magma-poor and volcanic rifted margins. Marine and Petroleum geology 43, 63-87.

Gac, S., Geoffroy, L., 2009. 3D Thermo-mechanical modelling of a stretched continental lithosphere containing localized low-viscosity anomalies (the soft-point theory of plate breakup). Tectonophysics $468,158-168$. 
Geoffroy, L., 2001. The structure of volcanic margins: some problematics from the NorthAtlantic/Labrador-Baffin system. Marine and Petroleum Geology 18, 463-469.

Geoffroy, L., 2005. Volcanic passive margins. Comptes Rendus Geoscience 337, 1395-1408.

Geoffroy, L., Burov, E.B., Werner, P., 2015. Volcanic passive margins: another way to break up continents. Scientific reports 5, 14828.

Gerya, T.V., 2010. Introduction to Numerical Geodynamic Modelling. Cambridge University Press, $345 \mathrm{pp}$.

Gerya, T.V., 2013. Three-dimensional thermomechanical modeling of oceanic spreading initiation and evolution. Physics of the Earth and Planetary Interiors 214, 35-52.

Gerya, T.V., Yuen, D.A., 2007. Robust characteristics method for modelling multiphase visco-elasto-plastic thermo-mechanical problems. Physics of the Earth and Planetary Interiors $163,83-105$.

Guillou-Frottier, L., Burov, E., Cloetingh, S., Le Goff, I., Deschamps, Y., Huet, B., Bouchot, V., 2012. Plume-induced dynamic instabilities near cratonic blocks: Implications for P-T-t paths and metallogeny. Global and Planetary Change 90-91, 37-50.

Gueydan, F., Morency, C., Brun, J.-P., 2008. Continental rifting as a function of lithosphere mantle strength. Tectonophysics 460, 83-93.

Halldórsson, S.A., Hilton, D.R., Scarsi, P., Abebe, T., Hopp, J., 2014. A common mantle plume source beneath the entire East African Rift System revealed by coupled helium-neon systematics. Geophysical Research Letters 41, 2304-2311.

Henry, C.D., 1989. Late Cenozoic Basin and Range structure in western Mexico adjacent to the Gulf of California. Geological Society of America Bulletin 101, 1147-1156. 
Huerta, A.D., Nyblade, A.A., Reusch, A.M., 2009. Mantle transition zone structure beneath Kenya and Tanzania: more evidence for a deep-seated thermal upwelling in the mantle. Geophysical Journal International 177, 1249-1255.

Huet, B., Le Pourhiet, L., Labrousse, L., Burov, E., Jolivet, L., 2011. Post-orogenic extension and metamorphic core complexes in a heterogeneous crust: the role of crustal layering inherited from collision. Application to the Cyclades (Aegean domain). Geophysical Journal International 184, 611-625.

Huismans, R.S., Beaumont, C., 2003. Symmetric and asymmetric lithospheric extension: Relative effects of frictional-plastic and viscous strain softening. Journal of Geophysical Research: Solid Earth 108, B10.

Huismans, R.S., Beaumont, C., 2008. Complex rifted continental margins explained by dynamical models of depth-dependent lithospheric extension. Geology 36, 163-166.

Huismans, R., Beaumont, C., 2011. Depth-dependent extension, two-stage breakup and cratonic underplating at rifted margins. Nature 473, 74-78.

Jammes, S., Huismans, R.S., 2012. Structural styles of mountain building: controls of lithospheric rheologic stratification and extensional inheritance. Journal of Geophysical Research: Solid Earth 117, B10.

Jordan, B.T., Grunder, A.L., Duncan, R.A., Deino, A.L., 2004. Geochronology of age progressive volcanism of the Oregon High Lava Plains: implications for the plume interpretation of Yellowstone. Journal of Geophysical Research: Solid Earth 109, B10.

Karato, S.I., Wu, P., 1993. Rheology of the Upper Mantle. Science 260, 771-778.

Kendall, J.M., Pilidou, S., Keir, D., Bastow, I.D., Stuart, G. W., Ayele, A., 2006. Mantle upwellings, melt migration and the rifting of Africa: Insights from seismic anisotropy. Geological Society, London, Special Publications 259, 55-72. 
Kendall, J.M., Stuart, G.W., Ebinger, C.J., Bastow, I.D., Keir, D., 2005. Magma-assisted rifting in Ethiopia. Nature 433, 146-148.

Kohlstedt, D.L., Evans, B., Mackwell, S.J., 1995. Strength of the lithosphere: constraints imposed by laboratory experiments. Journal of Geophysical Research: Solid Earth 100, 17587-17602.

Koptev A., Burov E., Calais E., Leroy S., Gerya T., Guillou-Frottier L., Cloetingh S., 2016. Contrasted continental rifting via plume-craton interaction: Applications to Central East African rift. Geoscience Frontiers 7, 221-236.

Koptev, A., Calais, E., Burov, E., Leroy, S., Gerya, T., 2015. Dual continental rift systems generated by plume-lithosphere interaction. Nature Geoscience 8, 388-392.

Le Pourhiet, L., Burov, E., Moretti, I., 2004. Rifting through a stack of inhomogeneous thrusts (the dipping pie concept). Tectonics 23.

Le Pourhiet, L., Huet, B., May, D.A., Labrousse, L., Jolivet, L., 2012. Kinematic interpretation of the 3D shapes of metamorphic core complexes. Geochemistry, Geophysics, Geosystems 13.

Le Pourhiet, L., May, D.A., Huile, L., Watremez, L., Leroy, S., 2017. A genetic link between transform and hyper-extended margins, Earth and Planetary Science Letters, accepted.

Li, X.H., Su, L., Chung, S.L., Li, Z.X., Liu, Y., Song, B., Liu, D.Y., 2005. Formation of the Jinchuan ultramafic intrusion and the world's third largest $\mathrm{Ni}-\mathrm{Cu}$ sulfide deposit: Associated with the $\sim 825$ Ma south China mantle plume? Geochemistry, Geophysics, Geosystems 6 .

Li, Z.X., Li, X.H., Kinny, P.D., Wang, J., 1999. The breakup of Rodinia: did it start with a mantle plume beneath South China? Earth and Planetary Science Letters 173, 171-181. 
Liao, J., Gerya, T., 2014. Influence of lithospheric mantle stratification on craton extension: Insight from two-dimensional thermo-mechanical modeling. Tectonophysics 631, 50-64.

Liao, J., Gerya, T., 2015. From continental rifting to seafloor spreading: Insight from 3D thermo-mechanical modeling. Gondwana Research 28, 1329-1343.

Lin, J., Purdy, G.M., Schouten, H., Sempere, J.C., Zervas, C., 1990. Evidence from gravity data for focused magmatic accretion along the Mid-Atlantic Ridge. Nature 344, 627-632.

Lizarralde D., Axen G.J., Brown H.E., Fletcher J.M., González-Fernández A., Harding A.J., Holbrook W.S., Kent G.M., Paramo P., Sutherland F., Umhoefer P.J., 2007. Variation in styles of rifting in the Gulf of California. Nature 448, 466-469.

Manatschal, G., Lavier, L., Chenin, P., 2015. The role of inheritance in structuring hyperextended rift systems: Some considerations based on observations and numerical modeling. Gondwana Research 27, 140-164.

May, D.A., Brown, J., Le Pourhiet, L., 2014. pTatin3D: High-performance methods for longterm lithospheric dynamics. In Proceedings of the International Conference for High Performance Computing, Networking, Storage and Analysis, 274-284.

May, D.A., Brown, J., Le Pourhiet, L., 2015. A scalable, matrix-free multigrid preconditioner for finite element discretizations of heterogeneous Stokes flow. Computer Methods in Applied Mechanics and Engineering 290, 496-523.

McKenzie, D., 1978. Some remarks on the development of sedimentary basins. Earth and Planetary Science Letters 40, 25-32.

Meigs, A., Scarberry, K., Grunder, A.L., Carlson, R.L., Ford, M.T., Fouch, M.J., Grove, T., Hart, W.K., Iademarco, M., Jordan, B.T., Milliard, J., 2009. Geological and geophysical perspectives on the magmatic and tectonic development, High Lava Plains and northwest Basin and Range. In: O'Connor, J.E., Dorsey, R.J., Madin, I.P. (Eds.), Volcanoes to 
Vineyards: Geologic Field Trips through the Dynamic Landscape of the Pacific Northwest: Geological Society of America Field Guide 15, 435-470.

Morgan, P., Seager, W.R., Golombek, M.P., 1986. Cenozoic thermal, mechanical and tectonic evolution of the Rio Grande rift. Journal of Geophysical Research: Solid Earth 91, 6263-6276.

Mulibo, G.D., Nyblade, A.A., 2013. The P and S wave velocity structure of the mantle beneath eastern Africa and the African superplume anomaly. Geochemistry, Geophysics, Geosystems 14, 2696-2715.

Nelson, W.R., Furman, T., Hanan, B., 2008. Sr, Nd, Pb and Hf evidence for two-plume mixing beneath the East African Rift System. Geochimica et Cosmochimica Acta Supplement 72, A676.

Nelson, W.R., Furman, T., van Keken, P.E., Shirey, S.B., Hanan, B.B., 2012. Os-Hf isotopic insight into mantle plume dynamics beneath the East African Rift System. Chemical Geology $320,66-79$.

Nyblade, A.A., 2011. The upper-mantle low-velocity anomaly beneath Ethiopia, Kenya, and Tanzania: Constraints on the origin of the African superswell in eastern Africa and plate versus plume models of mantle dynamics. Geological Society of America Special Papers 478, $37-50$

Nyblade, A.A., Brazier, R.A., 2002. Precambrian lithospheric controls on the development of the East African rift system. Geology 30, 755-758.

O’Donnell, J.P., Adams, A., Nyblade, A.A., Mulibo, G.D., Tugume, F., 2013 The uppermost mantle shear wave velocity structure of eastern Africa from Rayleigh wave tomography: constraints on rift evolution. Geophysical Journal International 194, 961-978.

Parsons, B., Richter, F.M., 1980. A relation between the driving force and geoid anomaly associated with mid-ocean ridges. Earth and Planetary Science Letters 51, 445-450. 
Pik, R., Deniel, C., Coulon, C., Yirgu, G., Marty, B., 1999. Isotopic and trace element signatures of Ethiopian flood basalts: evidence for plume-lithosphere interactions. Geochimica et Cosmochimica Acta 63, 2263-2279.

Pik, R., Marty, B., Hilton, D.R., 2006. How many mantle plumes in Africa? The geochemical point of view. Chemical Geology 226, 100-114.

Popov, A., Sobolev, S., 2008. SLIM3D: A tool for three-dimensional thermomechanical modeling of lithospheric deformation with elasto-visco-plastic rheology. Physics of the Earth and Planetary Interiors 171, 55-75.

Ring, U., 1994. The influence of preexisting structure on the evolution of the Cenozoic Malawi Rift (East African Rift system). Tectonics 13, 313-326.

Ring, U., 2014. The East African Rift system. Austrian Journal of Earth Sciences 107, 132146.

Saria, E., Calais, E., Stamps, D.S., Delvaux, D., Hartnady, C.J.H., 2014. Present-day kinematics of the East African Rift. Journal of Geophysical Research: Solid Earth 119, 35843600.

Schellart, W.P., 2004. Quantifying the net slab pull force as a driving mechanism for plate tectonics. Geophysical Research Letters 31.

Sengör, A.M.C., Burke, K., 1978. Relative timing of rifting and volcanism on Earth and its tectonic implications. Geophysical Research Letters 5, 419-421.

Sokoutis, D., Corti, G., Bonini, M., Brun, J.P., Cloetingh, S., Mauduit, T., Manetti, P., 2007. Modelling the extension of heterogeneous hot lithosphere. Tectonophysics 444, 63-79.

Stamps, D.S., et al., 2008. A kinematic model for the East African Rift. Geophysical Research Letters 35, L05304. 
Storey, B.C., 1995. The role of mantle plumes in continental breakup: case histories from Gondwanaland. Nature 377, 301.

Thieulot, C., 2011. FANTOM: Two- and three-dimensional numerical modelling of creeping flow for the solution of geological problems. Physics of the Earth and Planetary Interiors 188, 47-68.

Van Wijk, J.W., Blackman, D.K., 2005. Dynamics of continental rift propagation: the endmember modes. Earth and Planetary Science Letters 229, 247-258.

Vogt, K., Matenco, L., Cloetingh, S., 2017. Crustal mechanics control the geometry of mountain belts. Insights from numerical modelling. Earth and Planetary Science Letters 460, $12-21$.

Wagner, L., Forsyth, D.W., Fouch, M.J., James, D.E., 2010. Detailed three-dimensional shear wave velocity structure of the northwestern United States from Rayleigh wave tomography. Earth and Planetary Science Letters 299, 273-284.

Wang, X.C., Li, X.H., Li, W.X., Li, Z.X., 2007. Ca. 825 Ma komatiitic basalts in South China: First evidence for > $1500 \mathrm{C}$ mantle melts by a Rodinian mantle plume. Geology 35, 1103-1106.

Watremez, L., Burov, E., d'Acremont, E., Leroy, S., Huet, B., Pourhiet, L., Bellahsen, N., 2013. Buoyancy and localizing properties of continental mantle lithosphere: Insights from thermomechanical models of the eastern Gulf of Aden. Geochemistry, Geophysics, Geosystems 14, 2800-2817.

White, R.S., McKenzie, D., 1995. Mantle plumes and flood basalts. Journal of Geophysical Research: Solid Earth 100, 17543-17585. 
Willingshofer, E., Sokoutis, D., Luth, S., Beekman, F., Cloetingh, S., 2013. Subduction and deformation of the continental lithosphere in response to plate and crust-mantle coupling. Geology 41, 1239-1242.

Zeyen, H., Volker, F., Wehrle V., Fuchs K., Sobolev S.V., Altherr R., 1997. Styles of continental rifting: crust-mantle detachment and mantle plumes. Tectonophysics 278, 329352. 
Table 1. Controlling parameters of the numerical experiments.

\begin{tabular}{|c|c|c|c|c|}
\hline \multirow{3}{*}{$\begin{array}{c}\text { Experiment } \\
\text { title }\end{array}$} & \multicolumn{4}{|c|}{ Controlling parameters } \\
\hline & \multicolumn{2}{|c|}{ Lithosphere properties } & \multirow{2}{*}{$\begin{array}{c}\text { Horizontal } \\
\text { extension } \\
\text { velocities } \\
(\mathrm{mm} / \mathrm{yr})\end{array}$} & \multirow[t]{2}{*}{ Plume density } \\
\hline & $\begin{array}{c}\text { Type (rheology) of lower crust } \\
\text { (Supplementary Table 1) } \\
\text { WetQz - wet quartzite flow law; } \\
\mathrm{An}_{75} \text { - plagioclase flow law }\end{array}$ & $\begin{array}{c}\text { Temperature } \\
\text { at the Moho } \\
\left({ }^{\circ} \mathrm{C}\right)\end{array}$ & & \\
\hline 1. $R 1$ & 1 (WetQz) & 700 & 3 & Perple_X \\
\hline 2. $R$ l. $L c=A n_{75}$ & $2\left(\mathrm{An}_{75}\right)$ & 700 & 3 & Perple_X \\
\hline 3. $R 1 . T_{M h}=500^{\circ} \mathrm{C}$ & 1 (WetQz) & 500 & 3 & Perple_X \\
\hline 4. $R 1 . T_{M h}=600^{\circ} \mathrm{C}$ & 1 (WetQz) & 600 & 3 & Perple_X \\
\hline 5. $R 1 . T_{M h}=800^{\circ} \mathrm{C}$ & 1 (WetQz) & 800 & 3 & Perple_X \\
\hline 6. $R 1 . V_{\text {ext }}=1.5$ & 1 (WetQz) & 700 & 1.5 & Perple_X \\
\hline 7. $R 1 . V_{\text {ext }}=2$ & 1 (WetQz) & 700 & 2 & Perple_X \\
\hline 8. R1. $V_{e x t}=6$ & 1 (WetQz) & 700 & 6 & Perple_X \\
\hline 9. $R 1 . T_{M h}=600^{\circ} \mathrm{C}+V_{e x t}=1.5$ & 1 (WetQz) & 600 & 1.5 & Perple_X \\
\hline 10. $R 1 . T_{M h}=800^{\circ} C+V_{e x t}=1.5$ & 1 (WetQz) & 800 & 1.5 & Perple_X \\
\hline 11. $R 1 \cdot T_{M h}=600^{\circ} \mathrm{C}+V_{e x t}=6$ & 1 (WetQz) & 600 & 6 & Perple_X \\
\hline 12. $R 1 \cdot T_{M h}=800^{\circ} \mathrm{C}+V_{e x t}=6$ & 1 (WetQz) & 800 & 6 & Perple_X \\
\hline 13. R1.LightPlume & $1($ WetQz) & 700 & 3 & Perple_X-30 kg/m ${ }^{3}$ \\
\hline 14. R1.LightPlume $+V_{\text {ext }}=6$ & 1 (WetQz) & 700 & 6 & Perple_X-30 kg/m ${ }^{3}$ \\
\hline
\end{tabular}




\section{FIGURE CAPTIONS}

Figure 1. Reference model 1. 3D view of experiment evolution: a) rapid plume uplift and formation of localized zone of brittle deformation in the upper crust; b) fast opening of 600$\mathrm{km}$ wide rift basin due to combined effect of "active" and "passive" rifting; c) appearing of two narrow rifts associated with initiation of localized plume ascent; d) break-up of the continental lithosphere and development of single spreading zone considerably shifted from the mantle plume center. The plume material is shown in dark red. Blue to red colors indicate strain rate at the level of $10 \mathrm{~km}$ (i.e. in the upper crust).

Figure 2. Reference model 1. Surface topography evolution: domal uplift (a) is quickly replaced by subsidence and formation of rifted basin (b) that opens (c-e) significantly faster compared to the imposed external extension (half rate is $3 \mathrm{~mm} / \mathrm{yr}$ ): at $40 \mathrm{Myr}$ the amount of passive extension applied at the boundaries is $240 \mathrm{~km}$ while the width of formed depression is more than $700 \mathrm{~km}(\mathrm{f})$.

Figure 3. Reference model 1. Strain rate (left column) and compositional (right column) cross-sections: a) localized brittle deformation in the upper crust and distributed ductile strain into weak lower crust; b-d) crustal boudinage due to ductile flow in the lower crust; insequence migration of the brittle deformation leads to the opening of the rift basin; e) almost complete recrystallization of the plume material (note spatial position of the last melted segments); wide rift basin ( $800 \mathrm{~km})$ with less expressed fault boundaries; f) initiation of localized plume uplift and development of two faults zones cutting the entire lithosphere; g) continental break-up along right narrow rift (note that left rift is abandoned); decompressional 
melting of plume and lithospheric material due to its localized uplift underneath the spreading axis.

Spatial position of vertical cross-sections is shown on Figure 1. It is shifted to $250 \mathrm{~km}$ from the central part of the model domain and, consequently, does not pass through the plume tail. Given the quick lateral penetration of the plume material into the lower part of the lithospheric mantle, in the corresponding cross-sections the plume head is underlain by a thin layer of the remnant lithospheric mantle.

Figure 4. Model with a mafic lower crust (Model 2). 3D view of experiment evolution: a) highly distributed linear faults above laterally spread plume head; b-c) narrow rifting along two stretched zones; d) break-up of the continental lithosphere along one spreading axis situated above mantle plume center.

Figure 5. Model with a mafic lower crust (Model 2). Surface topography evolution: a) distributed small-offset faults over plume-induced central domal uplift; b-d) formation of two parallel depressions bounding by rift shoulders; e-f) one of these rift structures continues to develop into spreading axis while another one is decaying.

Figure 6. Model with a mafic lower crust (Model 2). Strain rate (left column) and compositional (right column) cross-sections: a-d) gradual broadening of diffuse brittle deformation in the crust and the lithospheric mantle over spreading plume head (note the lack of lower-crustal ductile flow and the absence of crustal boudinage); e) almost complete solidification of the plume material (note quasi-uniform lateral distribution of melted remains); f) localized deformation along two narrow rifts and associated with them localized 
ascent of the plume material; g) continental break-up along quasi-centered axis (note that another narrow rift is failed).

Figure 7. Model with a mafic lower crust (Model 2). Compositional cross-sections (at 70 Myr) showing that localized plume ascent varies not only across-strike but also along-strike. Yellow line highlights the position of the plume apex; the arrow indicates the direction of its dipping. Bulk of mantle plume is shown in red. Note that the vertical variations in the position of the plume apex reach $70-80 \mathrm{~km}$ that in rough accordance with conceptual model of volcanic margin segmentation based on magnetic fabric studies (Callot et al., 2001, 2002; Geoffroy, 2005; Gac and Geoffroy, 2009). See Section 4.2 for more discussion.

Figure 8. Strain rate cross-sections through a) model 3 (Moho temperature of $500^{\circ} \mathrm{C}$ ); b) model 4 (Moho temperature of $600^{\circ} \mathrm{C}$ ); c) reference model 1 (Moho temperature of $700^{\circ} \mathrm{C}$ ) and d) model 5 (Moho temperature of $800^{\circ} \mathrm{C}$ ) at $3 \mathrm{Myr}$.

Note that the area of brittle upper-crustal deformation narrows systematically with increasing Moho temperature.

Figure 9. Strain rate distributions at $10 \mathrm{~km}$ depth (the upper crust) for models $\mathbf{1}, \mathbf{4 - 6}$ and 8-12 characterized by different Moho temperatures $\left(T_{M h}\right): 600^{\circ} \mathrm{C}$ (left column), $700^{\circ} \mathrm{C}$ (middle column) and $800^{\circ} \mathrm{C}$ (right column) and far-field extension rates $\left(V_{\text {ext }}\right): 1.5 \mathrm{~mm} / \mathrm{yr}$ (upper row), $3 \mathrm{~mm} / \mathrm{yr}$ (middle row) and $6 \mathrm{~mm} / \mathrm{yr}$ (lower row). Elapsed time intervals are chosen to ensure identical amount of extension for all models shown. Blue circles indicate the borders of deformation zones in the central (narrowest) model sections (blue lines).

Note the systematic increase of the width of the deformation zone with decreasing geotherm and increasing far-field extensional rate. 
Figure 10. Strain rate cross-sections through a) model $\mathbf{3}$ (Moho temperature of $500^{\circ} \mathrm{C}$ ); b) model 4 (Moho temperature of $600^{\circ} \mathrm{C}$ ); c) reference model 1 (Moho temperature of $700^{\circ} \mathrm{C}$ ) and d) model 5 (Moho temperature of $800^{\circ} \mathrm{C}$ ) at $20 \mathrm{Myr}$.

Note the core complex mode of extension for model $\mathbf{1}\left(700^{\circ} \mathrm{C}\right)$ and $\mathbf{5}\left(800^{\circ} \mathrm{C}\right)$, wide rift mode for model $3\left(500^{\circ} \mathrm{C}\right)$, and intermediate mode for model $4\left(600^{\circ} \mathrm{C}\right)$. The width of the rift basin is governed by the lateral spreading of mantle plume material.

Figure 11. Strain rate cross-sections through a) model $\mathbf{3}$ (Moho temperature of $500^{\circ} \mathrm{C}$ ); b) model 4 (Moho temperature of $600^{\circ} \mathrm{C}$ ); c) reference model 1 (Moho temperature of $700^{\circ} \mathrm{C}$ ) and d) model 5 (Moho temperature of $800^{\circ} \mathrm{C}$ ) at the time of narrow rift localization.

Note the (quasi)centered position of narrow rift in case of (quasi)wide rift mode of initial crustal deformation $\left(500^{\circ} \mathrm{C}\right.$ and $600^{\circ} \mathrm{C}$ at Moho depth; models 3 and $\mathbf{4}$, respectively), and considerably shifted narrow rifts for core complex-like models $\left(700^{\circ} \mathrm{C}\right.$ and $800^{\circ} \mathrm{C}$ at $\mathrm{Moho}$ depth; models $\mathbf{1}$ and $\mathbf{5}$, respectively).

Figure 12. Timing of the transition from wide to narrow rift as a function of initial Moho temperature. Triangle and squares represent core complex and wide rift modes of initial crustal extension, respectively, whereas triangle inside square refers to mixed mode. White triangles and squares show models with weak felsic lower crust and the reference value (3 $\mathrm{mm} / \mathrm{yr}$ ) of far-field extension (models 1, 3-5). Gray square represents model 2 characterized by a stronger mafic lower-crustal rheology; black triangles show the models with different external spreading half-rate ( 2 and $6 \mathrm{~mm} / \mathrm{yr}$; models $\mathbf{7}$ and $\mathbf{8}$, respectively).

Note the linear dependence between time and Moho isotherm, strongly non-linear effect of the variations in far-field velocities and close time for different modes of extension (compare the reference model $\mathbf{1}$ (white triangle at $700^{\circ} \mathrm{C}$ ) and model $\mathbf{2}$ (gray square)). 
Figure 13. Variability of final continental break-up geometries in models 1-2, 5, 8, 13-14. Models 1 (a) and 2 (b) are characterized by single break-up zone; model 5 (c) demonstrates two symmetrical spreading centers; in case of models 8 (d) and 14 (f), two overlapping breakup zones are interconnected by strike-slip faults; model 13 (e) shows the most complex pattern resembling the configuration of East African rifts around Tanzanian craton (see Figure 14a).

Figure 14. a) Tectonic setting of the central part of the East African Rift System: Tanzanian craton embraced by active magmatic (eastern) and amagmatic (western) rift branches. Black lines indicate major faults (Corti et al., 2013). The grey line shows the edges of the Tanzanian craton. Red color indicates low velocity zones imaged at the depth of $200 \mathrm{~km}$ by S-wave tomography (O'Donnell et al., 2013); b) east-west seismic P-wave velocity mantle tomography profile (Mulibo and Nyblade, 2013) showing two zones of hot material around Tanzanian craton: more intensive negative anomaly underneath magmatic Eastern branch and less intensive one below amagmatic Western branch; c) 3D view of the main features for the model 14; d) vertical cross-sections of the material phase distribution for the model $\mathbf{1 4}$. Note that very trivial in terms of initial setting model $\mathbf{1 4}$ evolves into complex strain and material phase patterns providing good fit with observed contrasted East African rift branches. 


\section{SUPPLEMENTARY FIGURE CAPTIONS}

Supplementary Figure 1. Results of numerical resolution test: a-c) low-resolution model (149 $\times 149 \times 69$ nodes $)$; d-f $)$ middle-resolution model $(197 \times 197 \times 85$ nodes $)$; g-i) high-resolution model $(297 \times 297 \times 133$ nodes $)$ corresponding to the reference model 1 (see also Figures 1-3). Strain weakening (see Supplementary Methods, Eqs. 18-19) is linearly scaled to the grid step: $\varepsilon_{1}=0.12$ for low-resolution model, $\varepsilon_{1}=0.16$ for middle-resolution model, and $\varepsilon_{1}=0.25$ for high-resolution reference model 1.

Supplementary Figure 2. Model without the mantle plume (see Burov and Gerya (2014) for more detail): a) 3D view; b) surface topography; c) strain rate cross-section; d) compositional cross section.

Supplementary Figure 3. Series of strain rate cross-sections illustrating the evolution of a-c) model 3 (Moho temperature of $500^{\circ} \mathrm{C}$ ); d-f) model 4 (Moho temperature of $600^{\circ} \mathrm{C}$ ); g-i) reference model 1 (Moho temperature of $700^{\circ} \mathrm{C}$ ); j-1) model 5 (Moho temperature of $800^{\circ} \mathrm{C}$ ). 

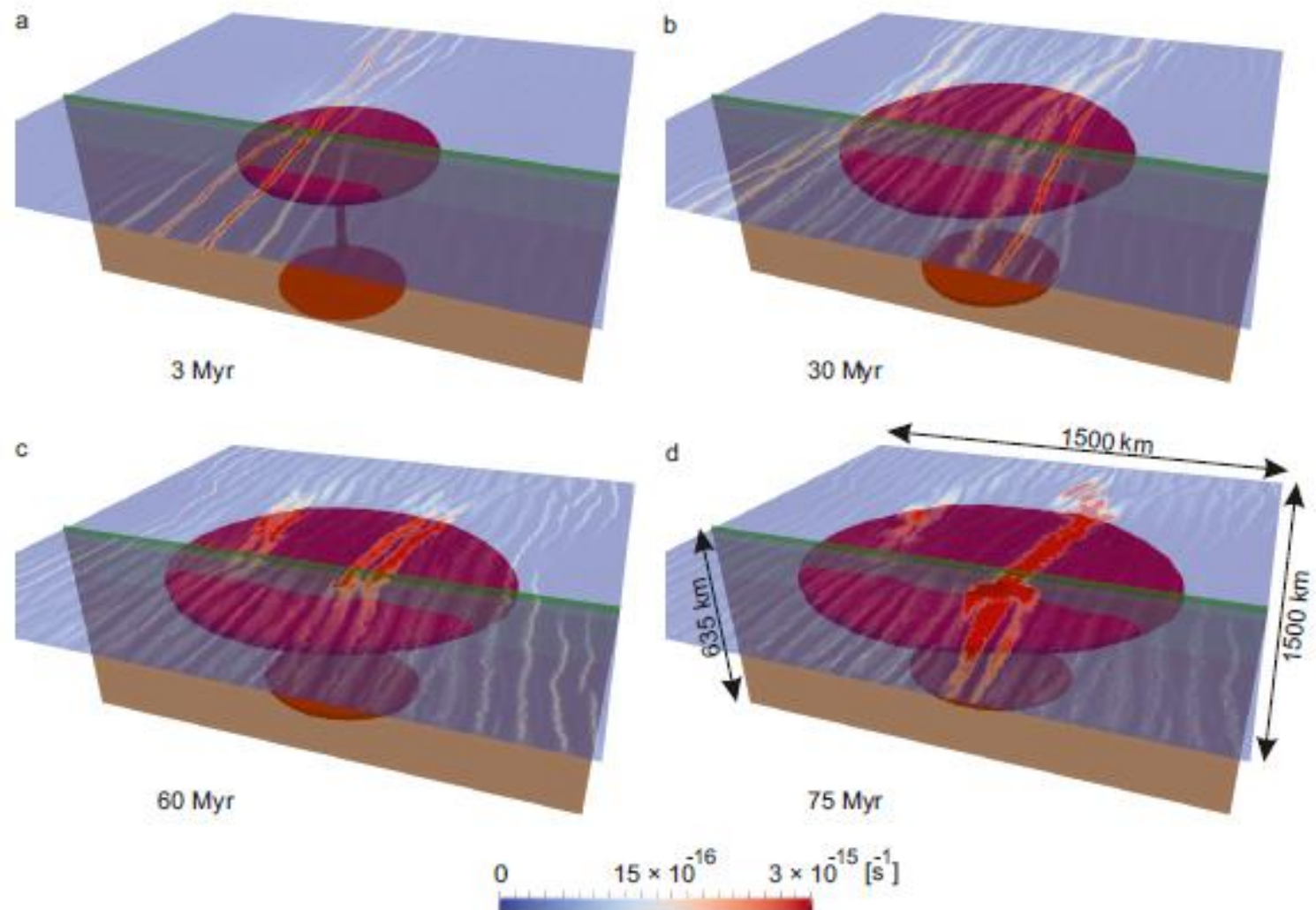

Figure 1. Reference model 1.3D view of experiment evolution: a) rapid plume uplift and formation of localized zone of brittle deformation in the upper crust; b) fast opening of 600 -km wide rift basin due to combined effect of "active" and "passive" rifting; c) appearing of two narrow rifts associated with initiation of localized plume ascent; d) break-up of the continental lithosphere and development of single spreading zone considerably shifted from the mantle plume center. The plume material is shown in dark red. Blue to red colors indicate strain rate at the level of $10 \mathrm{~km}$ (i.e. in the upper crust). 

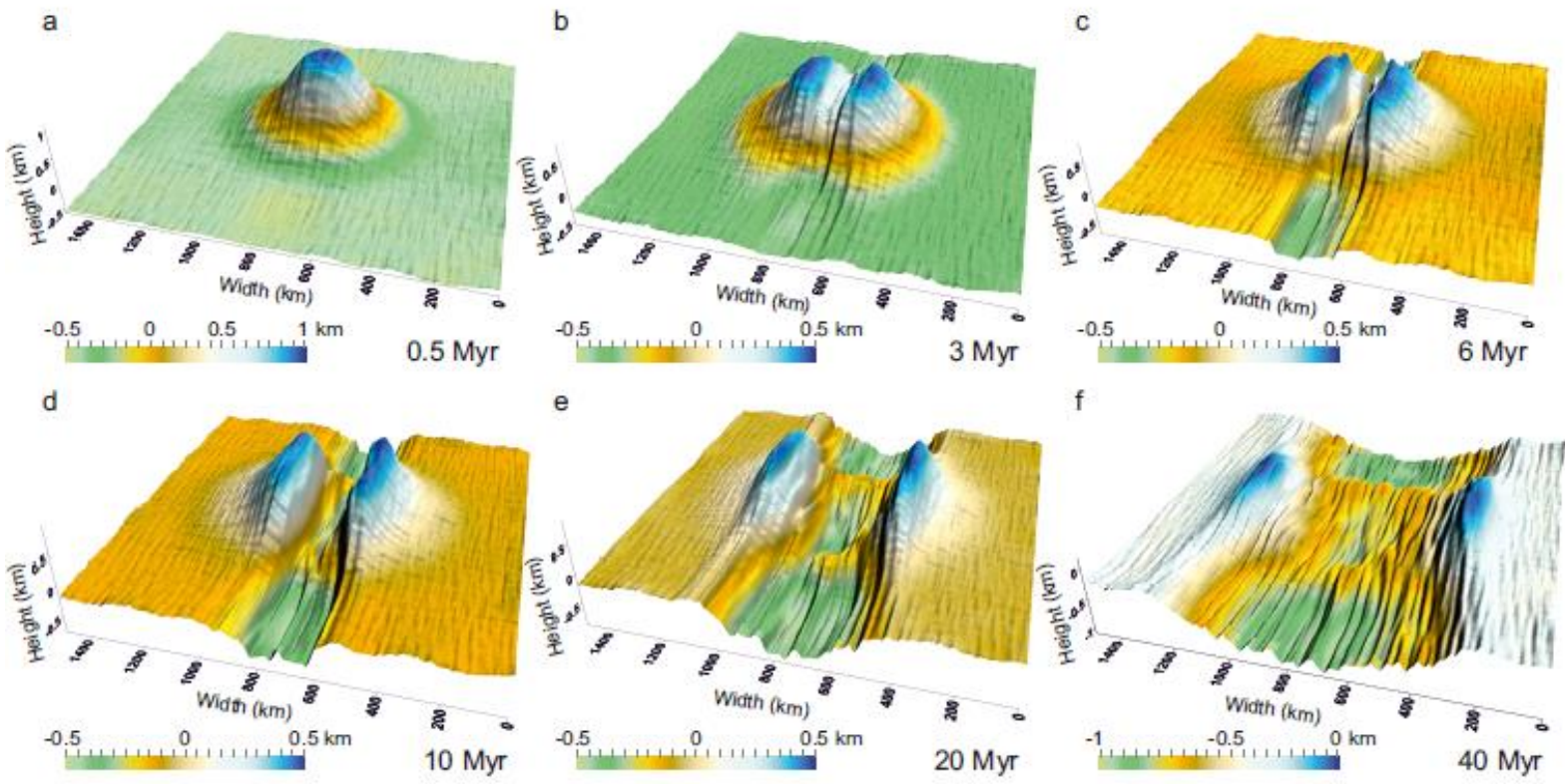

Figure 2. Reference model 1. Surface topography evolution: domal uplift (a) is quickly replaced by subsidence and formation of rifted basin (b) that opens (c-e) significantly faster compared to the imposed external extension (half rate is $3 \mathrm{~mm} / \mathrm{yr}$ ): at $40 \mathrm{Myr}$ the amount of passive extension applied at the boundaries is $240 \mathrm{~km}$ while the width of formed depression is more than $700 \mathrm{~km}(\mathrm{f})$. 

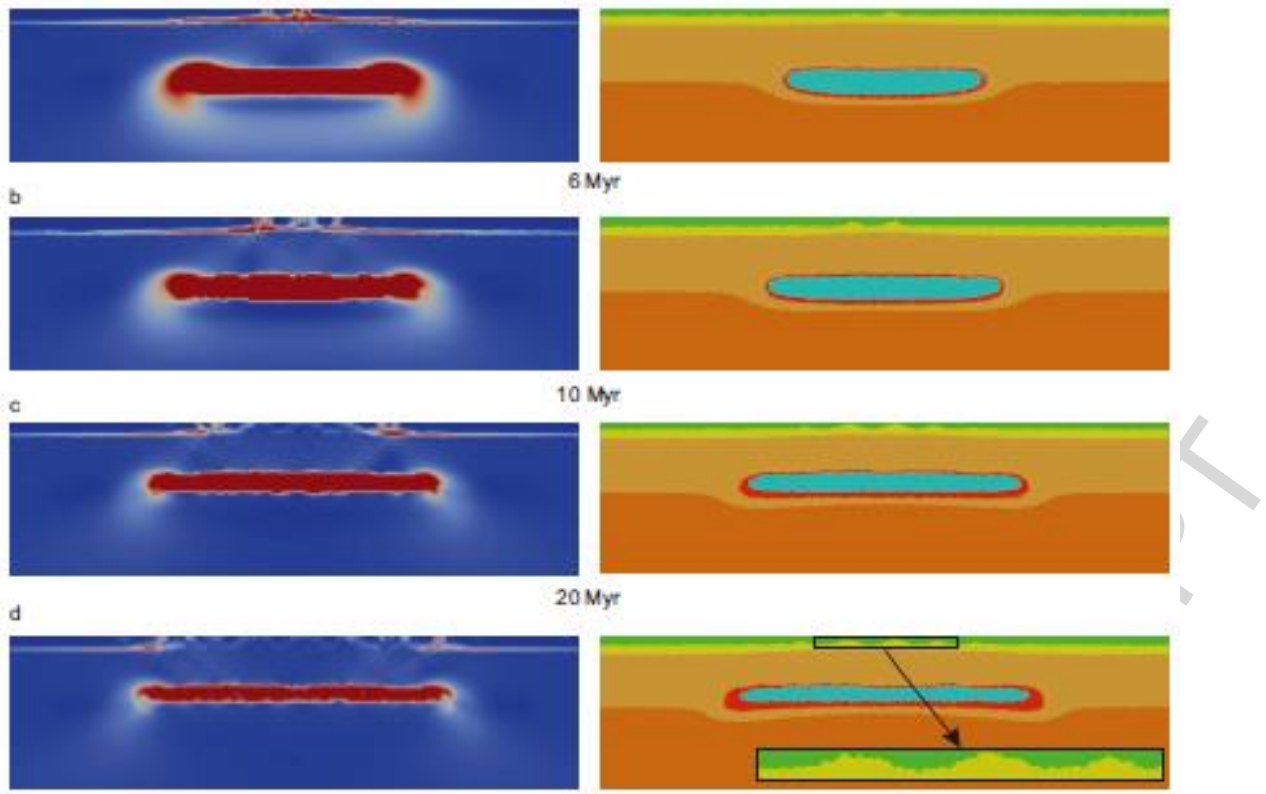

$30 \mathrm{Myr}$
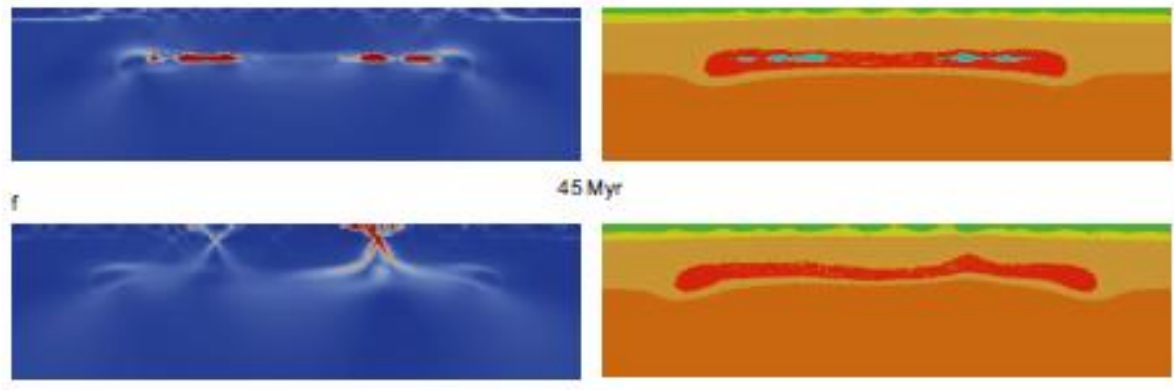

g

$65 \mathrm{Myr}$

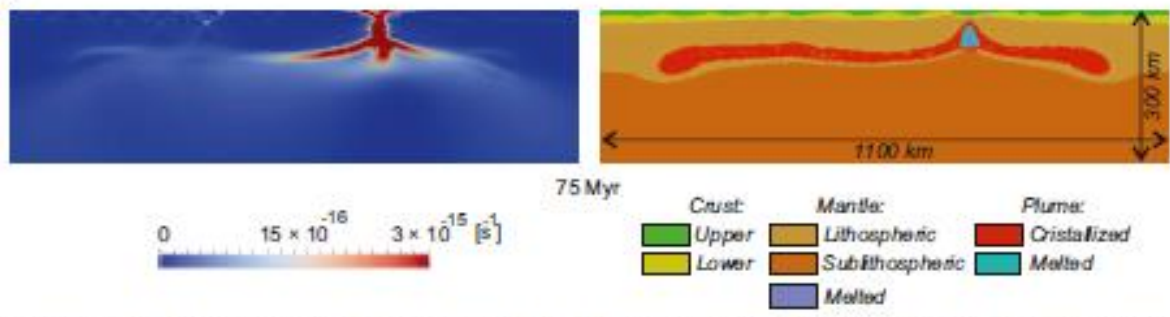

Figure 3. Reference model 1. Strain rate (left column) and compositional (right column) crosssections: a) localized brittle deformation in the upper crust and distributed ductile strain into weak lower crust; b-d) crustal boudinage due to ductile flow in the lower crust; in-sequence mi gration of the brittle deformation leads to the opening of the rift basin; e) almost complete recrysta llization of the plume material (note spatial position of the last melted segments); wide rift basin $(\sim 800 \mathrm{~km})$ with less expressed fault boundaries; $f$ ) initiation of localized plume uplift and development of two faul ts zones cutting the entire lithosphere; g) continental break-upa long right narrow rift (note that left rift is abandoned); decompressional melting of plume and lithospheric material due to its localized upl iftundemeath the spreading axis.

Spatial position of vertical cross-sections is shown on Figure 1. It is shifted to $250 \mathrm{~km}$ from the central part of the model domain and, consequently, does not pass through the plume tail. Given the quick lateral penetration of the plume material into the lower part of the lithospheric mantle, in the corresponding cross-sections the plume head is underlain by a thin layer of the remnant lithospheric mantle. 
a
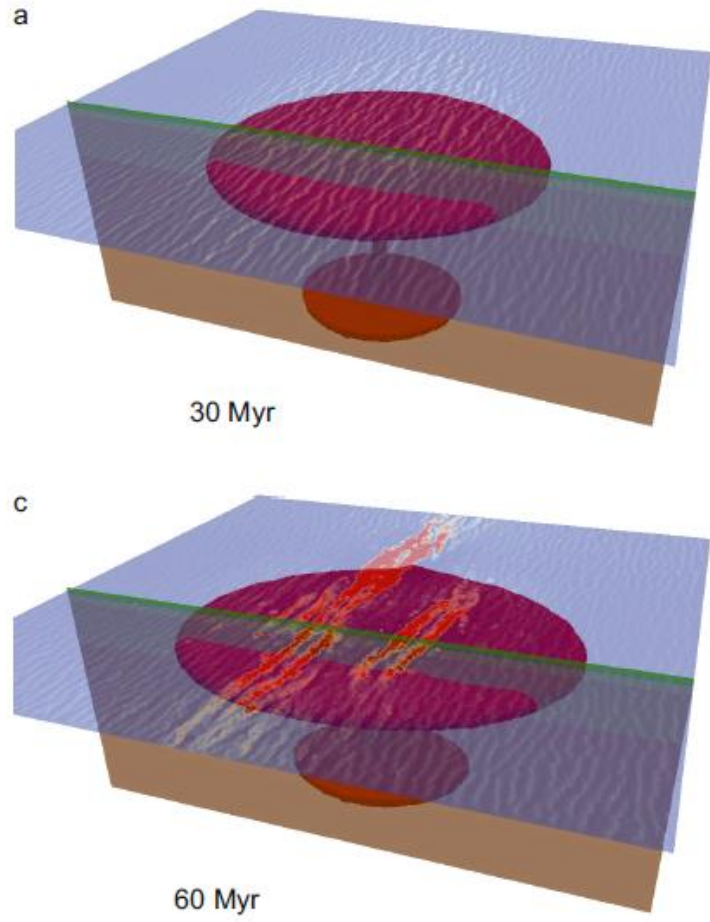

0 b
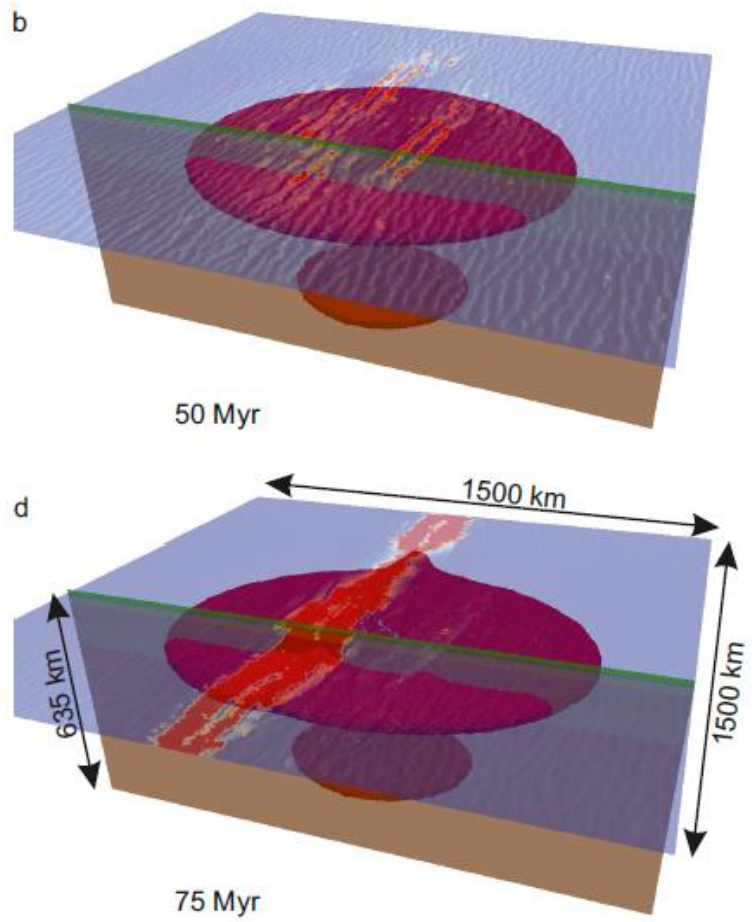

$5 \times 10^{-16} \quad 1 \times 10^{-15}\left[\mathrm{~s}^{-1}\right]$

Figure 4. Model with a mafic lower crust (Model 2). 3D view of experiment evolution: a) highly distributed linear faults above laterally spread plume head; b-c) narrow rifting along two stretched zones; d) break-up of the continental lithosphere along one spreading axis situated above mantle plume center. 
a

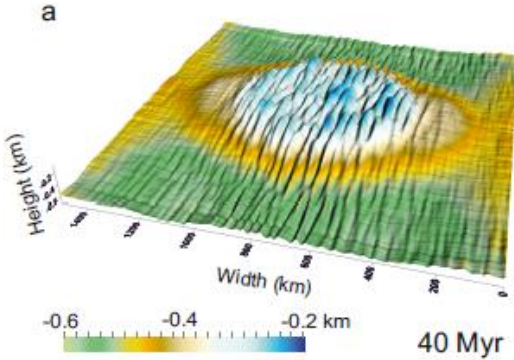

d

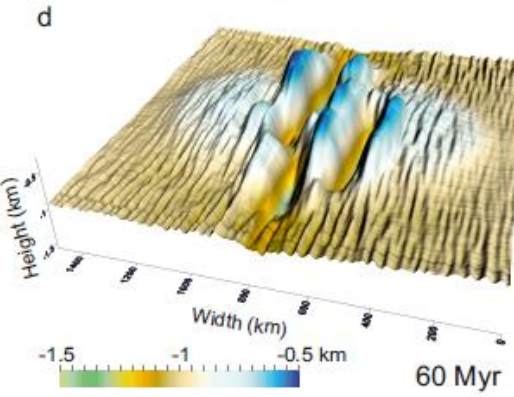

b

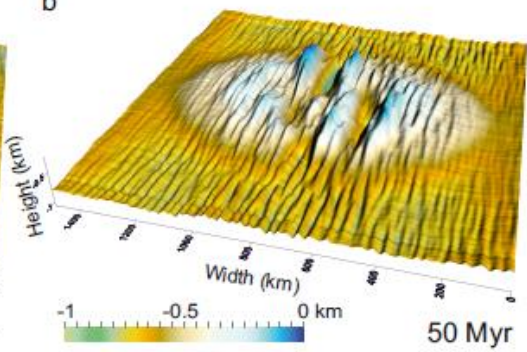

e

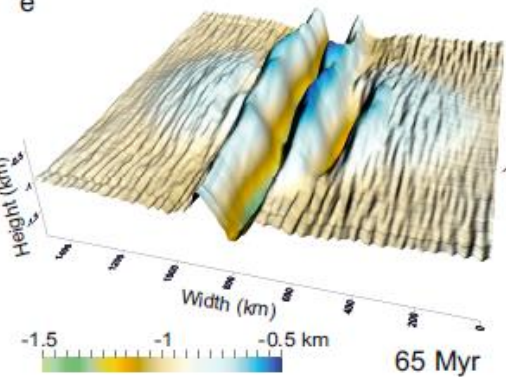

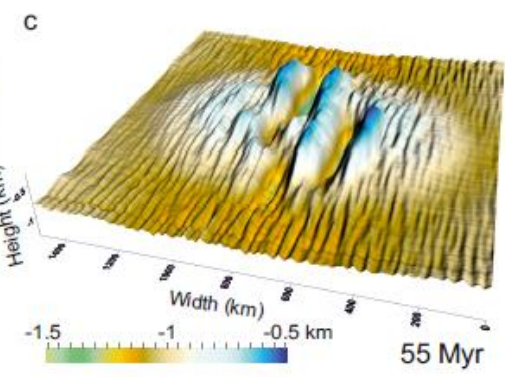

f

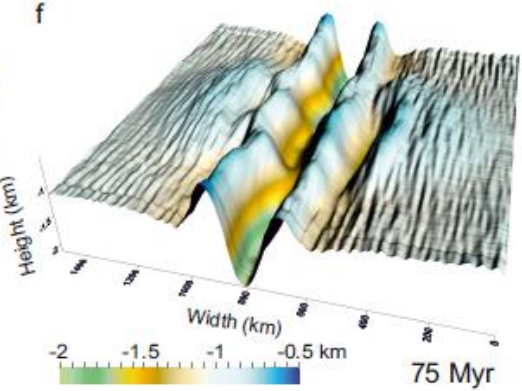

Figure 5. Model with a mafic lower crust (Model 2). Surface topography evolution: a) distributed small-offset faults over plume-induced central domal uplift; b-d) formation of two parallel depressions bounding by rift shoulders; e-f) one of these rift structures continues to develop into spreading axis while another one is decaying. 

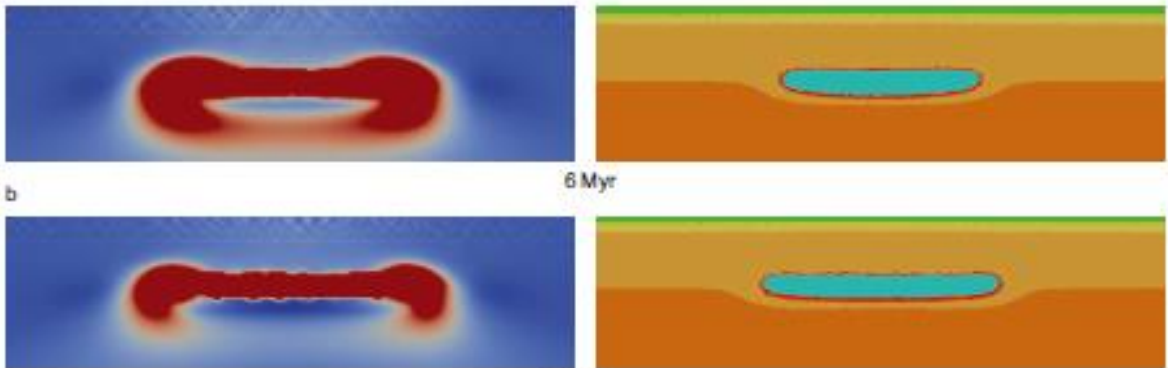

$10 \mathrm{Myr}$
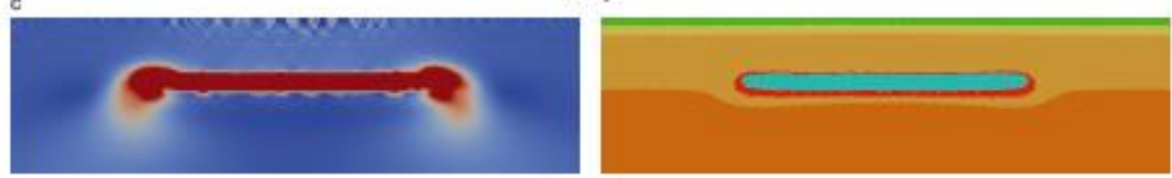

$20 \mathrm{Myr}$

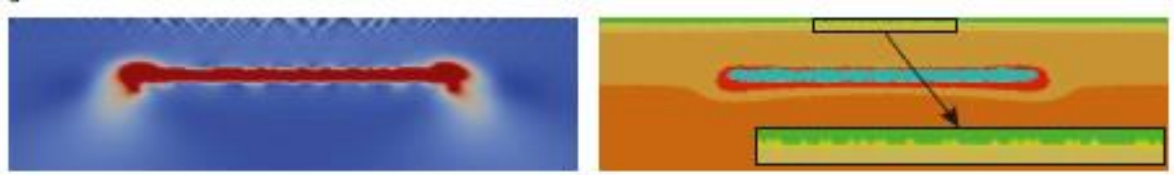

$30 \mathrm{Myr}$

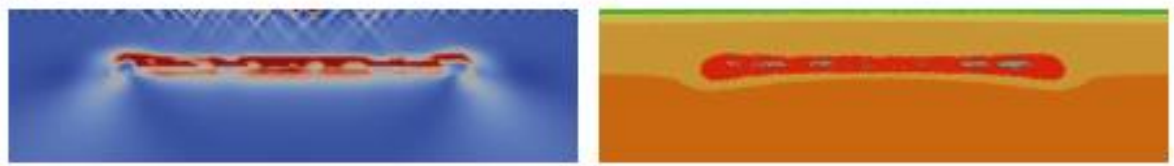

$40 \mathrm{Myr}$

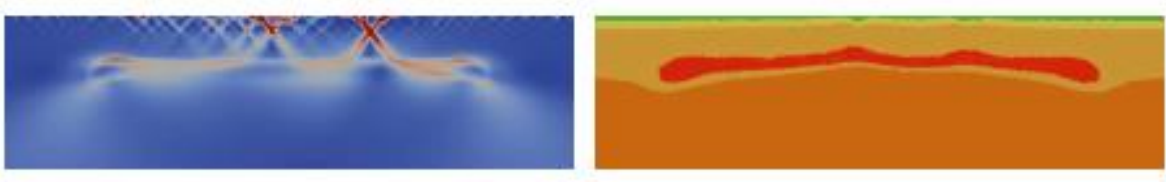

g

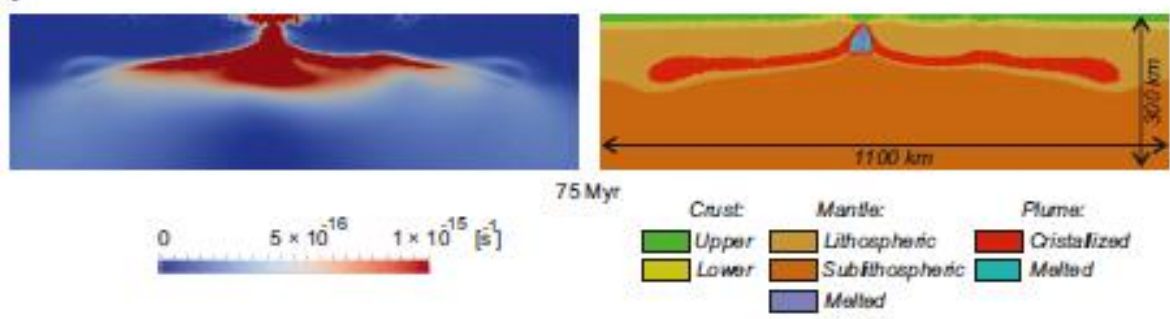

Figure 6. Model with a mafic lower crust (Model 2). Strain rate (left column) and compositional (right column) cross-sections: a-d) gradual broadening of diffusebrittle deformation in the crust and the lithospheric mantle over spreading plume head (note the lack of lower-crustal ductile flow and the absence of crustal boudinage); e) almost complete solidification of the plume material (note quasi-uniform lateral distribution of melted remains); f) localized deformation along two narrow rifts and associated with them localize dascent of the plume material; g) cont inental break-up along quasi-centered axis (note that another narrow rift is failed). 
a

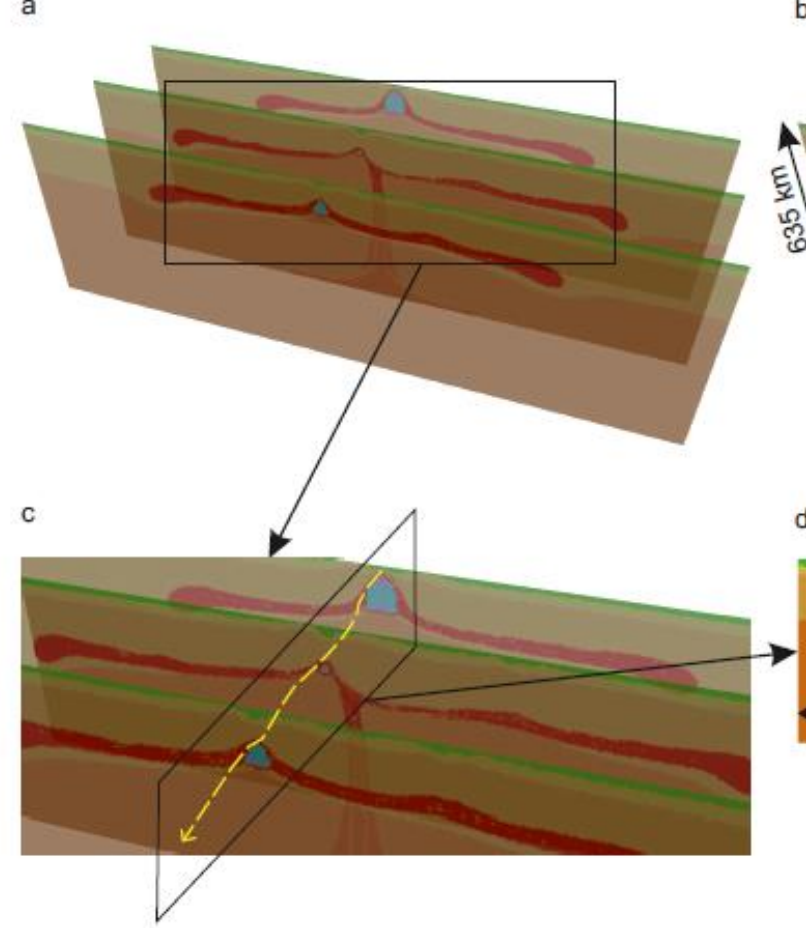

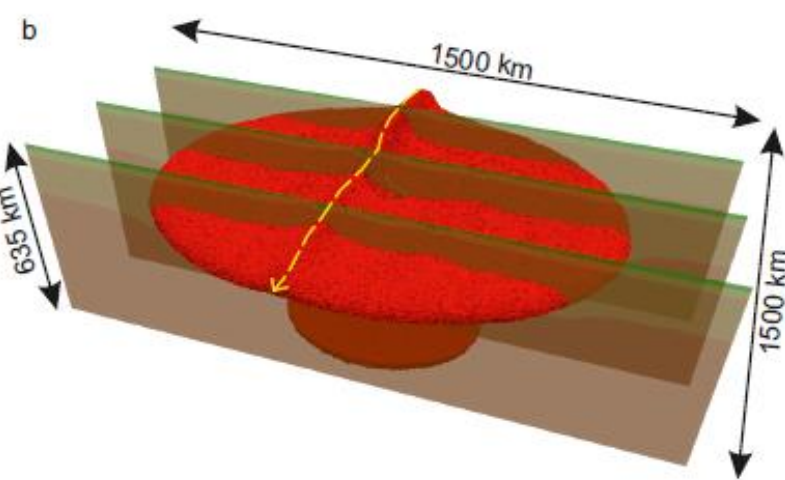

d
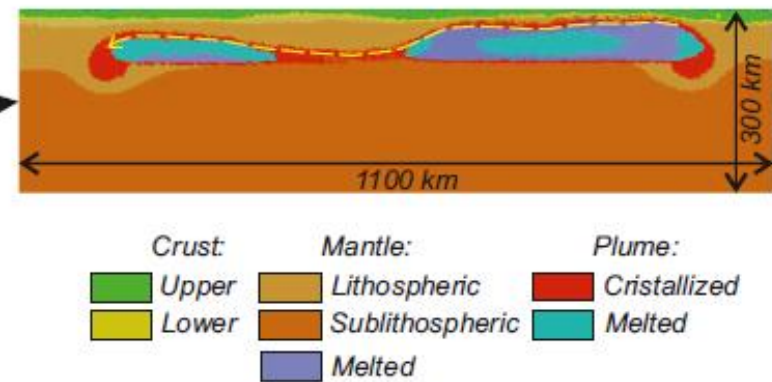

Figure 7. Model with a mafic lower crust (Model 2). Compositional cross-sections (at $70 \mathrm{Myr}$ ) showing that localized plume ascent varies not only across-strike but also along-strike. Yellow line highlights the position of the plume apex; the arrow indicates the direction of its dipping. Bulk of mantle plume is shown in red. Note that the vertical variations in the position of the plume apex reach $70-80 \mathrm{~km}$ that in rough accordance with conceptual model of volcanic margin segmentation based on magnetic fabric studies (Callot et al., 2001, 2002; Geoffroy, 2005; Gac and Geoffroy, 2009). See Section 4.2 for more discussion. 


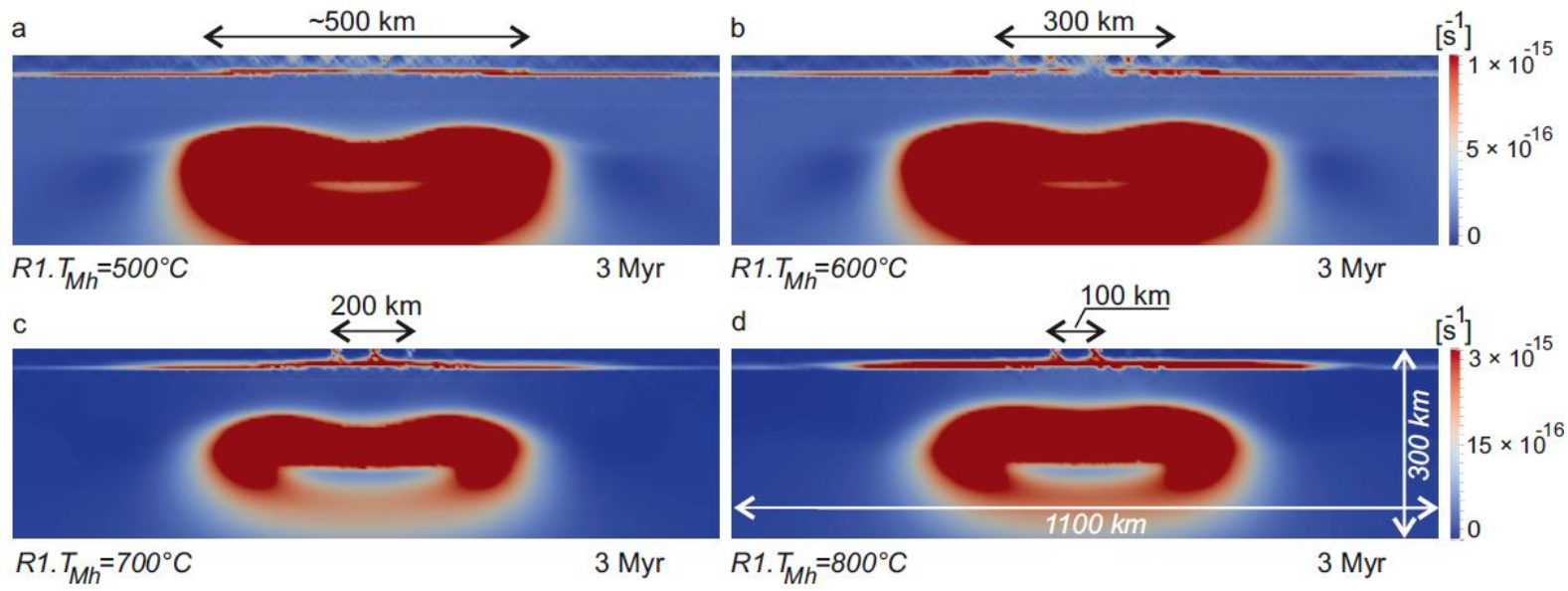

Figure 8. Strain rate cross-sections through a) model 3 (Moho temperature of $500^{\circ} \mathrm{C}$ ); b) model 4 (Moho temperature of $600^{\circ} \mathrm{C}$ ); c) reference model 1 (Moho temperature of $700^{\circ} \mathrm{C}$ ) and d) model 5 (Moho temperature of $800^{\circ} \mathrm{C}$ ) at $3 \mathrm{Myr}$.

Note that the area of brittle upper-crustal deformation narrows systematically with increasing Moho temperature. 

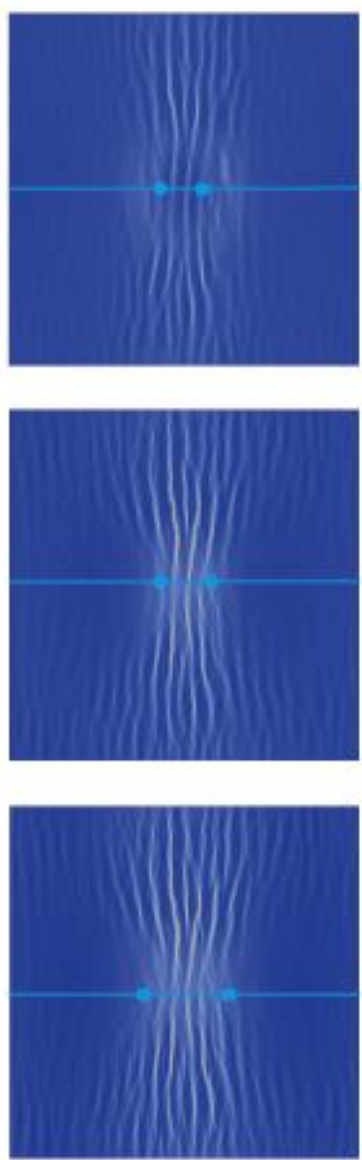

$T_{M h}=600^{\circ} \mathrm{C}$
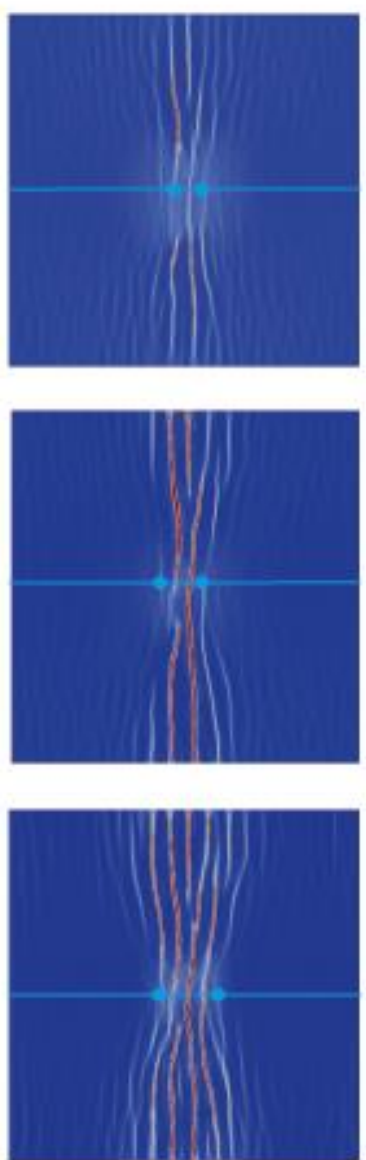

$T_{M n}=700^{\circ} \mathrm{C}$
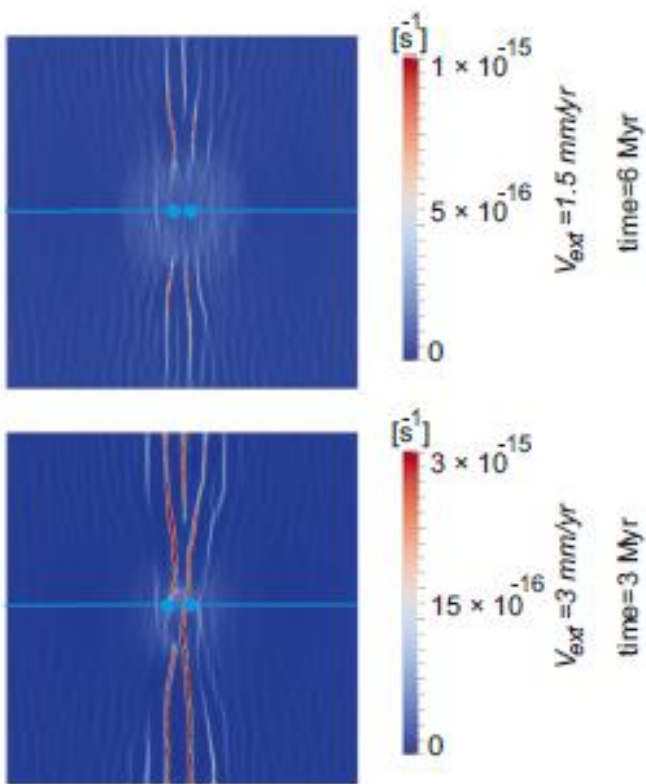

$1500 \mathrm{~km}$

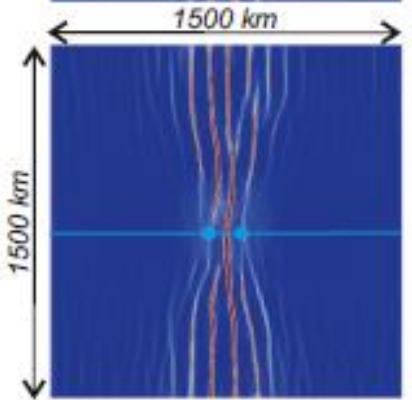

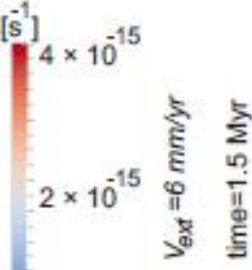

$T_{M n}=800^{\circ} \mathrm{C}$

Figure 9. Strain rate distributions at $10 \mathrm{~km}$ depth (the upper crust) for models $1,4-6$ and 8-12 characterized by different Moho temperatures (TMh): $600^{\circ} \mathrm{C}$ (left column), $700^{\circ} \mathrm{C}$ (middle column) and $800^{\circ} \mathrm{C}$ (right column) and far-field extension rates (Vext): $1.5 \mathrm{~mm} / \mathrm{yr}$ (upper row), $3 \mathrm{~mm} / \mathrm{yr}$ (middle row) and $6 \mathrm{~mm} / \mathrm{yr}$ (lower row). Elapsed time intervals are chosen to ensure identical amount of extension for all models shown. Blue circles indicate the borders of deformation zones in the central(narrowest) model sections (blue lines).

Note the systematic increase of the width of the deformation zone with decreasing geotherm and increasing far-field extensional rate. 


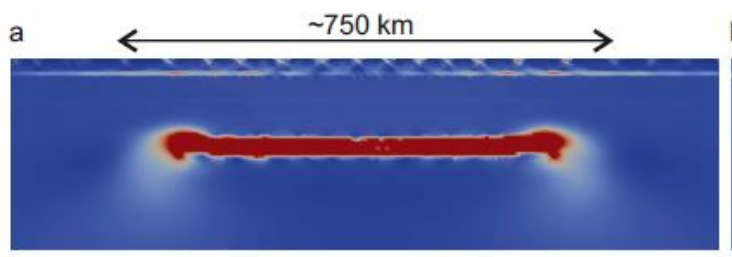

R1. $T_{M h}=500^{\circ} \mathrm{C}$

$20 \mathrm{Myr}$

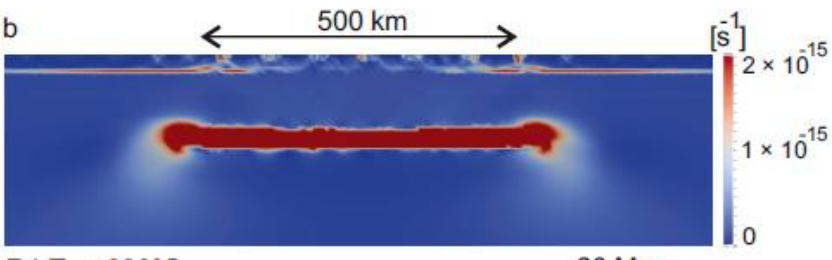

C

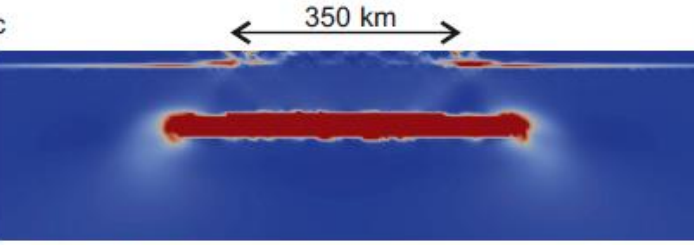

R1. $\mathrm{T}_{\mathrm{Mh}}=700^{\circ} \mathrm{C}$

$20 \mathrm{Myr}$

R1. $T_{M h}=600^{\circ} \mathrm{C}$

$20 \mathrm{Myr}$

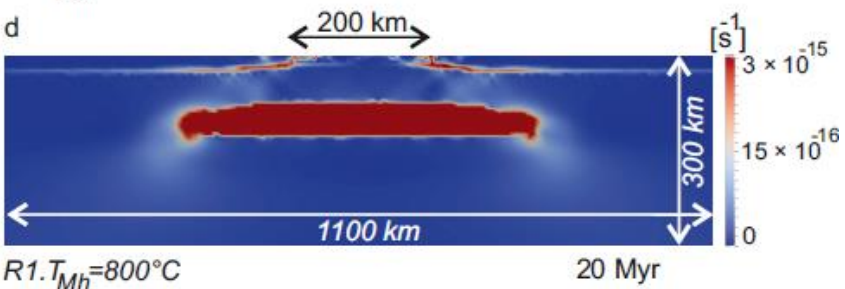

Figure 10. Strain rate cross-sections through a) model 3 (Moho temperature of $500^{\circ} \mathrm{C}$ ); b) model 4 (Moho temperature of $600^{\circ} \mathrm{C}$ ); c) reference model 1 (Moho temperature of $700^{\circ} \mathrm{C}$ ) and d) model 5 (Moho temperature of $800^{\circ} \mathrm{C}$ ) at $20 \mathrm{Myr}$.

Note the core complex mode of extension for model $1\left(700^{\circ} \mathrm{C}\right)$ and $5\left(800^{\circ} \mathrm{C}\right)$, wide rift mode for model $3\left(500^{\circ} \mathrm{C}\right)$, and intermediate mode for model $4\left(600^{\circ} \mathrm{C}\right)$. The width of the rift basin is governed by the lateral spreading of mantle plume material. 


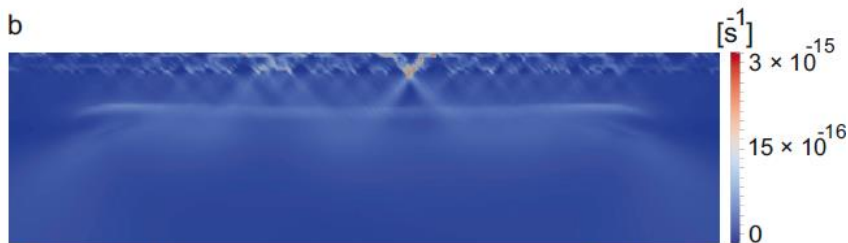

R1. $T_{M h}=500^{\circ} \mathrm{C}$

$95 \mathrm{Myr}$

R1. $T_{M h}=600^{\circ} \mathrm{C}$

$80 \mathrm{Myr}$

d

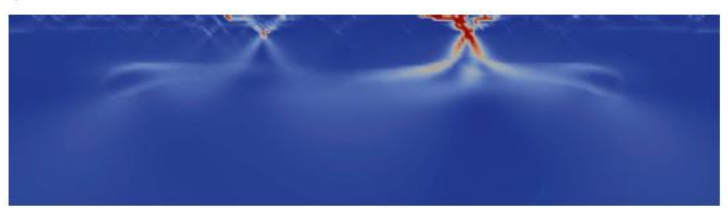

R1. $T_{M h}=700^{\circ} \mathrm{C}$

$65 \mathrm{Myr}$

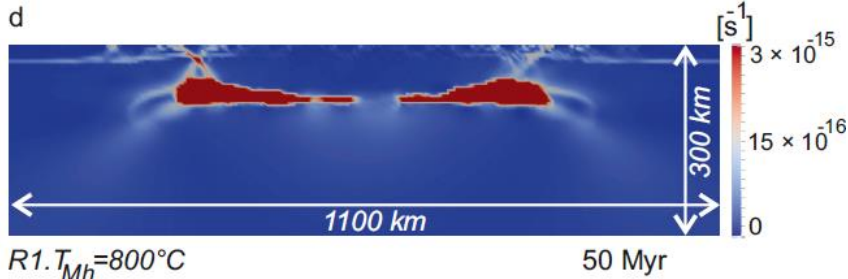

Figure 11. Strain rate cross-sections through a) model 3 (Moho temperature of $500^{\circ} \mathrm{C}$ ); b) model 4 (Moho temperature of $600^{\circ} \mathrm{C}$ ); c) reference model 1 (Moho temperature of $700^{\circ} \mathrm{C}$ ) and d) model 5 (Moho temperature of $800^{\circ} \mathrm{C}$ ) at the time of narrow rift localization.

Note the (quasi)centered position of narrow rift in case of (quasi)wide rift mode of initial crustal deformation $\left(500^{\circ} \mathrm{C}\right.$ and $600^{\circ} \mathrm{C}$ at Moho depth; models 3 and 4, respectively), and considerably shifted narrow rifts for core complex-like models $\left(700^{\circ} \mathrm{C}\right.$ and $800^{\circ} \mathrm{C}$ at Moho depth; models 1 and 5, respectively). 


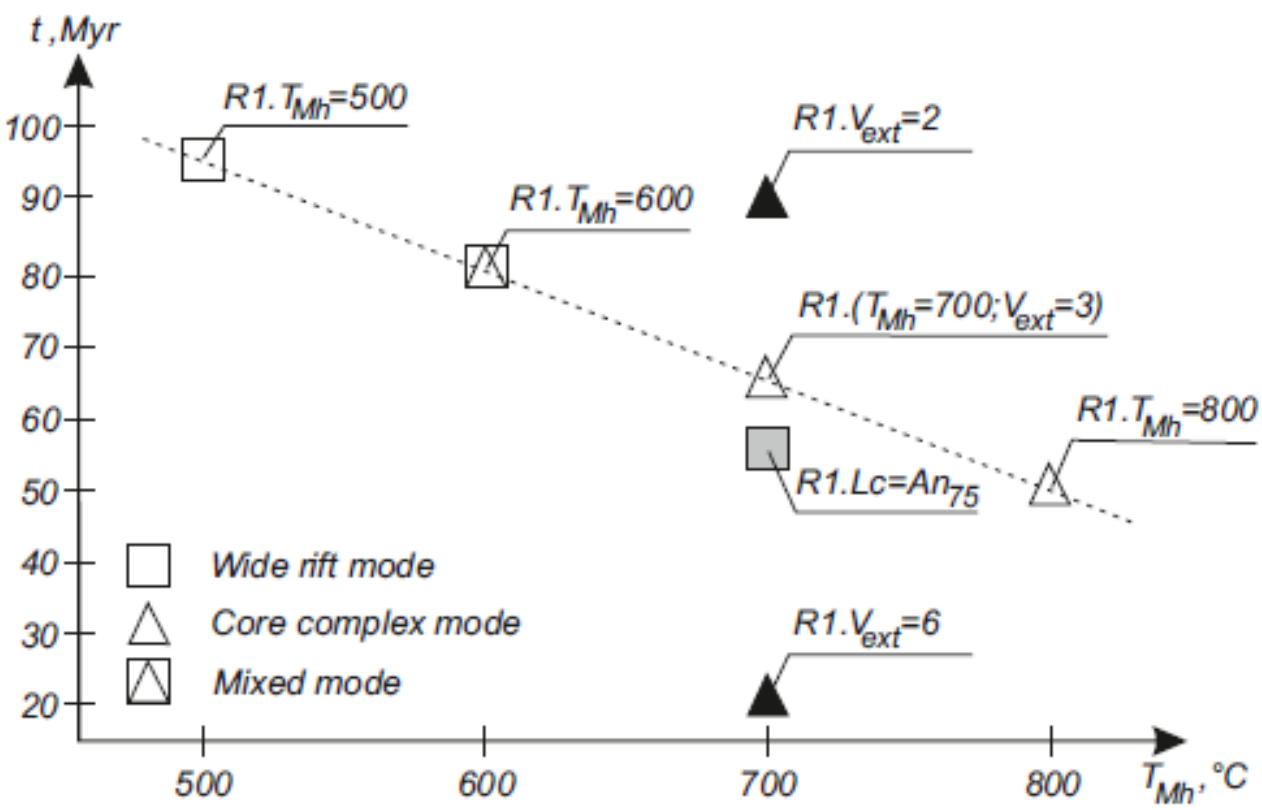

Figure 12. Timing of the transition from wide to narrow rift as a function of initial Moho temperature. Triangle and squares represent core complex and wide rift modes of initial crustal extension, respectively, whereas triangle inside square refers to mixed mode. White triangles and squares show models with weak felsic lower crust and the reference value ( $3 \mathrm{~mm} / \mathrm{yr})$ of farfield extension (models 1, 3-5). Gray square represents model 2 characterized by a stronger mafic lower-crustal rheology; black triangles show the models with different external spreading half-rate ( 2 and $6 \mathrm{~mm} / \mathrm{yr}$; models 7 and 8 , respectively).

Note the linear dependence between time and Moho isotherm, strongly non-linear effect of the variations in far-field velocities and close time for different modes of extension (compare the reference model 1 (white triangle at $700^{\circ} \mathrm{C}$ ) and model 2 (gray square)). 

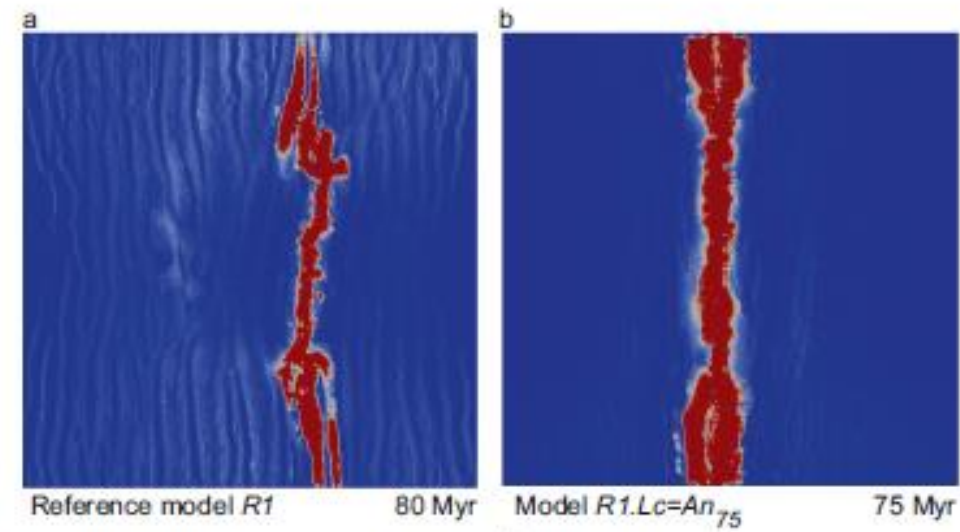

Reference model $R 1$

$80 \mathrm{Myr}$
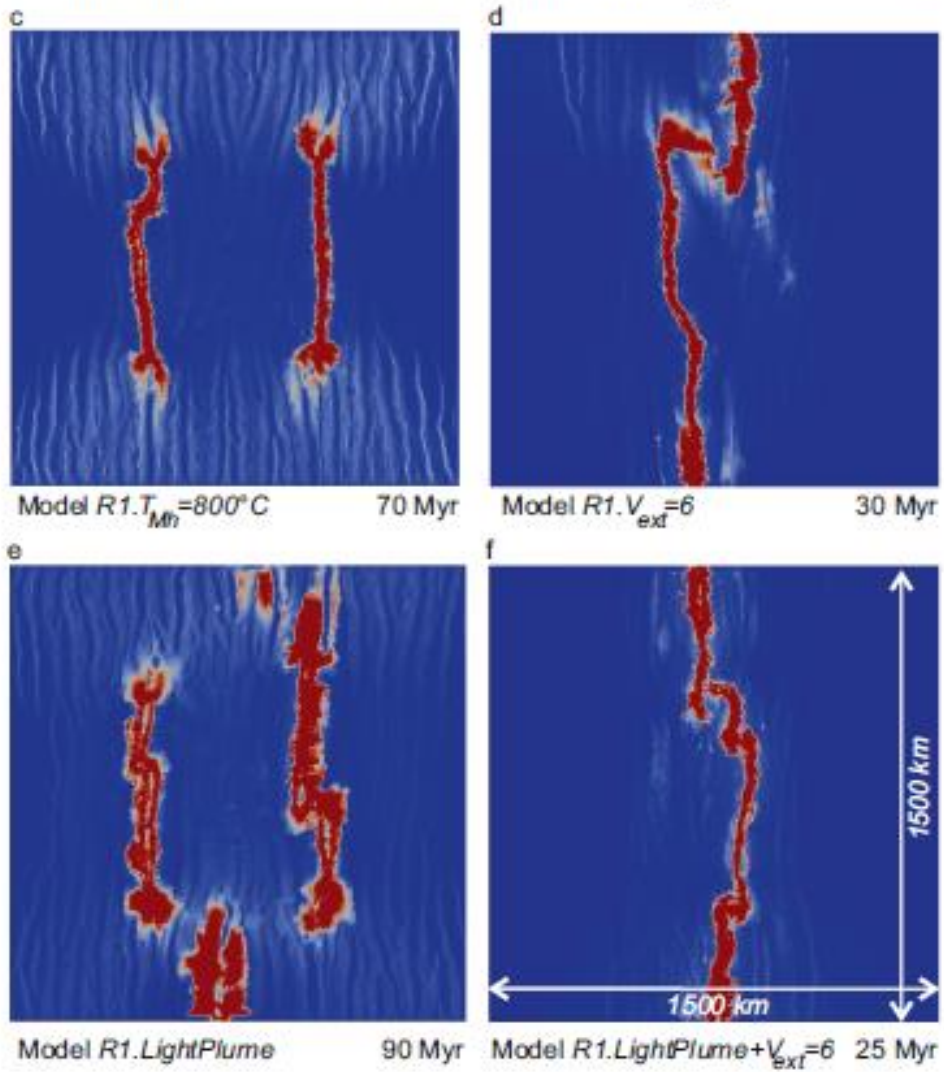

Model R1.LightPlume

$90 \mathrm{Myr}$ Model R1.LighPlume+ $\mathrm{Ext}_{\mathrm{x}}=625 \mathrm{Myr}$

$$
0 \quad 15 \times 10^{-16} \quad 3 \times 10^{-15}\left[\mathrm{~s}^{-1}\right]
$$

Figure 13. Variability of final continental break-up geometries in models 1-2, 5, 8, 13-14. Models 1 (a) and 2 (b) are characterized by single break-up zone; model 5 (c) demonstrates two symmetrical spreading centers; in case of models 8 (d) and 14 (f), two overlapping break-up zones are interconnected by strike-slip faults; model 13 (e) shows the most complex pattern resembling the configuration of East African rifts around Tanzanian craton (see Figure 14a). 


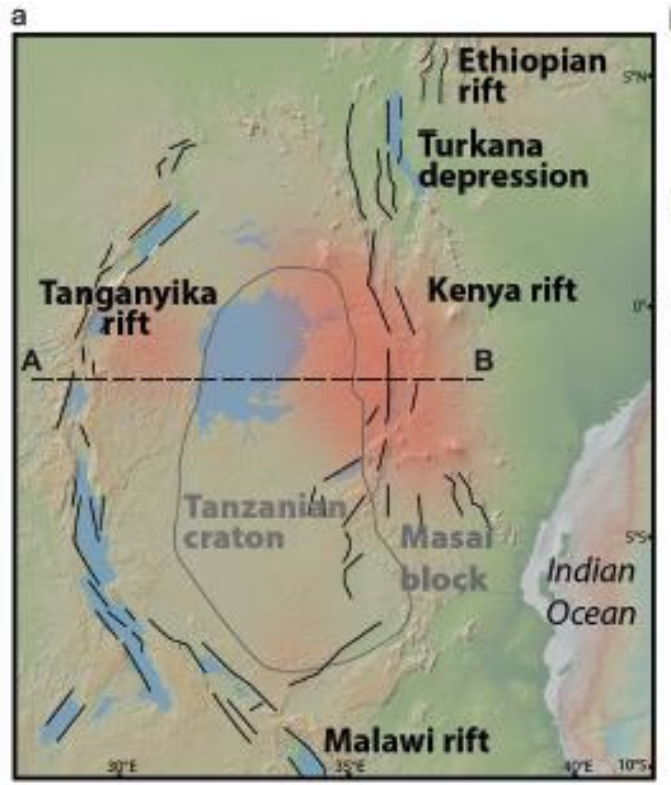

b
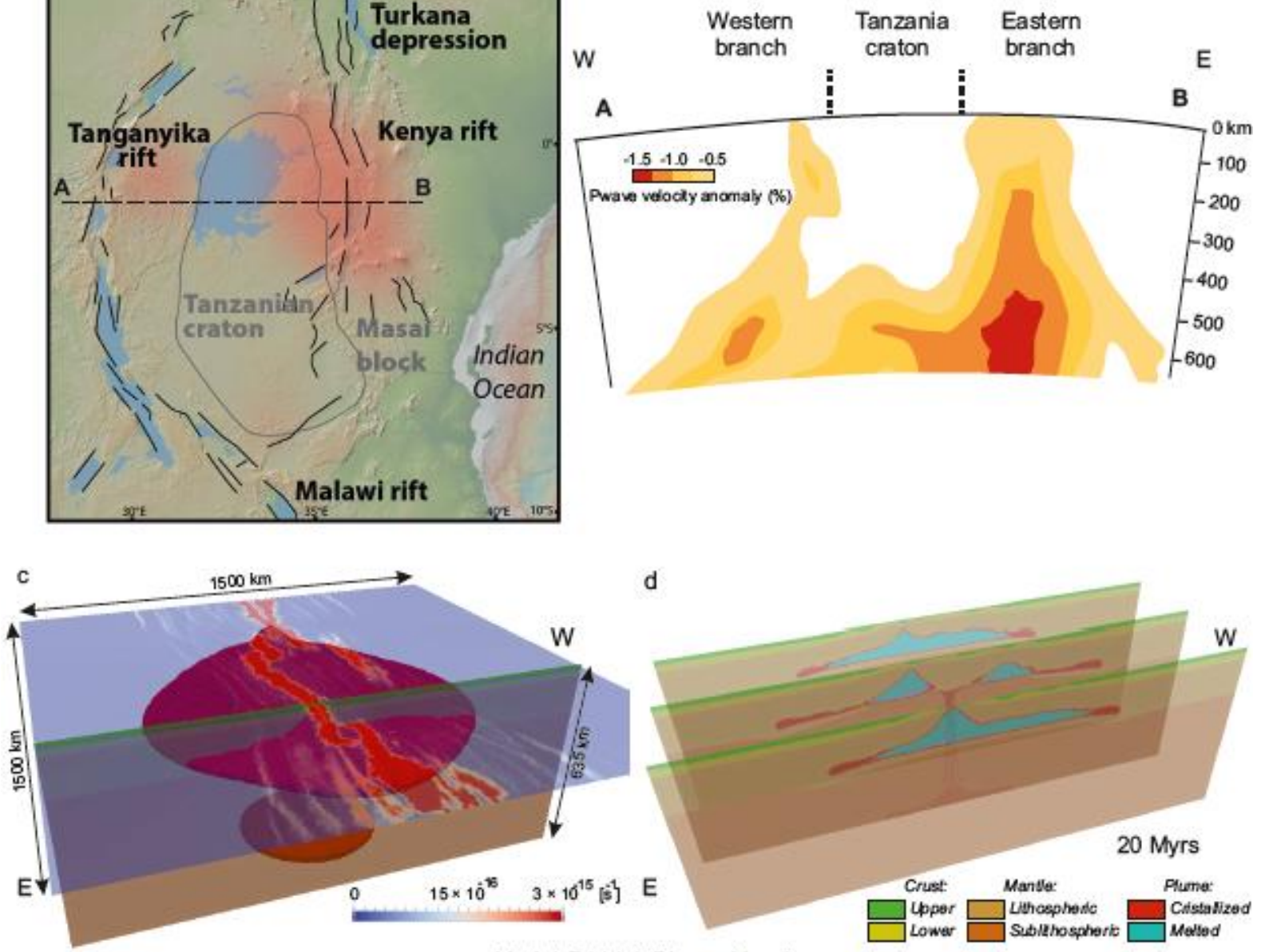

d

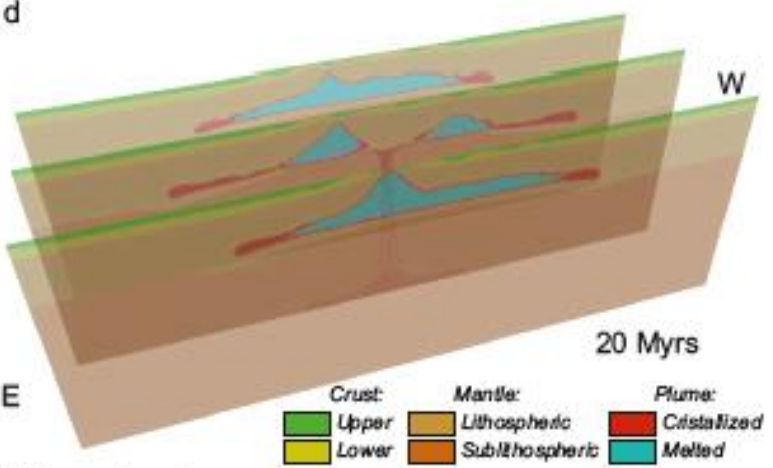

Model R1.LightPlume $+V_{\text {ext }}=6$

Figure 14. a) Tectonic setting of the central part of the East African Rift System: Tanzanian craton embraced by active magmatic (eastern) and amagmatic (western) rift branches. Black lines indicate major faults (Corti et al., 2013). The grey line shows the edges of the Tanzanian craton. Red color indicates low velocity zones imaged at the depth of $200 \mathrm{~km}$ by S-wave tomography (ODomell et al., 2013); b) east-west seismic P-wave velocity mantle tomography profile (Muliboand Nyblade, 2013) showing twozones of hot material around Tanzanian craton: more intensive negative anomaly undemeath magmatic Eastern branch and less intensive one below amagmatic Western branch; c) 3D view of the main features for the model 14; d) vertical cross-sections of the material phase distribution for the model 14. Note that very trivial in terms of initial setting model 14 evolves into complex strain and material phase patterns providing good fit withobserved contrasted East African rift branches. 

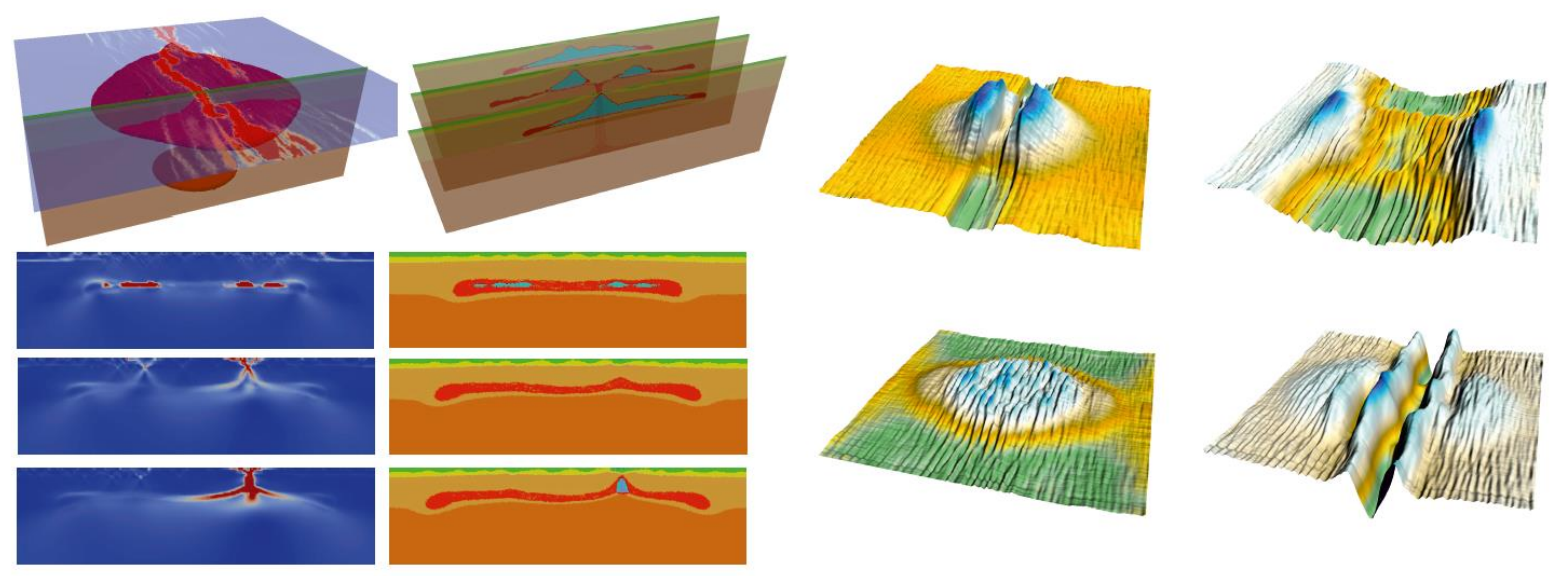

Graphical abstract 


\section{Research highlights:}

1. Rheological coupling favors wide rift mode of initial extension.

2. Mechanically decoupled lithosphere is extended according to core complex mode.

3. Localized uplift of the mantle plume invokes a rapid transfer to the narrow rifting.

4. Asymmetry of break-up seems to be intrinsic characteristic of plume-induced rifting. 